HID 41 (2014)

\title{
LOS ASIENTOS DE LA SANTA HERMANDAD CON LOS CONCEJOS ANDALUCES $(1478)^{1}$
}

\author{
THE ENTRIES OF THE HOLY BROTHERHOOD WITH THE \\ ANDALUSIAN COUNCILS (1478)
}

\section{Antonio Collantes de Terán SÁnchez Universidad de Sevilla}

RESUMEN: Este trabajo analiza los asientos establecidos entre los diputados generales de la Hermandad y varios concejos andaluces, por medio de los cuales se trató de poner fin a una serie de tensiones y conflictos que jalonó el primer año de vida de la institución en Andalucía. Dichos asientos, de los que se han conservado algunos y de otros han llegado referencias más o menos indirectas, fueron el resultado de una serie de negociaciones, iniciadas a partir de la Junta de PintoMadrid, en las que se acordaron tres cuestiones fundamentalmente: la liquidación de las deudas que los concejos venían arrastrando desde los primeros momentos de su integración, los recursos en hombres y dinero que debían poner a disposición de la Hermandad y la estructura orgánica local y provincial.

Palabras Claves: Santa Hermandad, Andalucía, Reyes Católicos, siglo XV, concejo, asientos.

ABSTRACT: This paper analyses the entries between the Brotherhood's general deputies and several Andalusian councils, through which it was tried to end a series of tensions and conflicts that marked out the first months of the life of the institution in Andalusia. These entries, some of which have been preserved and we have more or less indirect references from some others, were the result of a series of negotiations, promoted from the Junta of Pinto-Madrid, in which it was basically agreed three matters: the settlement of the debts that the councils were dogging since the first moments of their creation, the economical and human resources they should put at the Brotherhood's disposal and the local and county organical structure.

KeYwords: Holy Brotherhood, Andalusia, Catholic Kings, $15^{\text {th }}$ century, councils, entries.

1. Este trabajo se ha efectuado en el marco del proyecto de I+D+i HAR2011-26218 del MICINN "Fiscalidad y Sociedad en la Corona de Castilla al sur del Tajo" (Universidad de Málaga), integrante de la red de investigación sobre fiscalidad hispana (siglos XIII-XVIII) "Arca Comunis", http://www. arcacomunis.uma.es. 
Como toda institución que comienza, los inicios de la Santa Hermandad establecida por los Reyes Católicos no fueron fáciles por el contexto político-financiero en que tuvo lugar y por los intereses no siempre coincidentes de los distintos afectados. De ahí que el análisis de esa fase inicial, que se intuye larga y compleja, como en su día señalara Sánchez Benito ${ }^{2}$, sea de gran importancia, pues es necesario conocer las circunstancias y los mecanismos concretos en virtud de los cuales la institución se fue implantando en el conjunto de la Corona castellana. Sin lugar a dudas, como han puesto de relieve los escasos trabajos que han abordado la mencionada fase, a juzgar por la bibliografía que he podido utilizar ${ }^{3}$, la consulta de los archivos locales se hace imprescindible, aunque dicha necesidad se ve lastrada por las importantes pérdidas documentales que han experimentado. Es esta constatación la que me ha llevado a presentar aquí los asientos establecidos entre los diputados generales de la Hermandad y diversos concejos andaluces, como resultado último de negociaciones entre ambas partes, y situarlos en el contexto financiero de los citados concejos.

Aunque la aceptación formal de la Hermandad por parte de las ciudades y nobleza andaluzas se había producido en 1477, todavía a comienzos del año siguiente aquella no era total, pues algunas localidades no acataron los requerimientos, y entre las que la habían aceptado no existía una plena integración, siendo su financiación uno de los motivos que lo impidieron ${ }^{4}$. Dado que en la Junta General de Pinto y Madrid, celebrada en los meses de febrero y marzo de 1478, se había aprobado prórrogarla por tres años, debió considerarse que era el momento de poner orden en Andalucía, para lo cual los reunidos acordaron enviar una delegación con la finalidad de proceder a la integración definitiva. Para dicho cometido fueron designados los siguientes diputados generales: el tesorero Juan de Ortega, el contador mayor Alfonso de Quintanilla y el regidor de Salamanca Juan de Almaraz.

En la sesión capitular del concejo sevillano del 13 de abril de 1478, el procurador de la ciudad en la mencionada Junta, Cristóbal de Mosquera, dio cuenta de los acuerdos tomados en Madrid, haciendo la advertencia de que aún no los habían visto los monarcas 5 . Luego, el tesorero Juan de Ortega presentó un poder de la Junta General, que explicitaba el desembarco de los representantes enviados

2. J.M Sánchez Benito. "Observaciones sobre la Hermandad castellana en tiempos de Enrique IV y los Reyes Católicos”, Espacio, Tiempo y Forma. Serie III, Historia Medieval, 15 (2002), p. 228 y ss.

3. Entre los casos estudiados cabe citar Y. Guerrero Navarrete. "La Hermandad de 1476 y Burgos. Un factor decisivo en la transformación del poder municipal a fines de la Edad Media", Anuario de Estudios Medievales, 16 (1986), p. 533-555. J.M Sánchez Benito, D.C. Morales Muñiz. "La implantación de la Hermandad General en tierras de la nobleza: los estados del duque de Alba (1476-1479), En la España Medieval, 16 (1993), p. 265-286.

4. Sobre el mencionado proceso cfr. A. Collantes de Terán Sánchez. "Los comienzos de la Santa Hermandad de los Reyes Católicos en Andalucía (1476-1481)", Minervae Baeticae. Boletín de la Real Academia Sevillana de Buenas Letras, 42 (2014), en prensa.

5. "E la dicha carta vista e leýda, el dicho Xristóual de Mosquera dixo que las escripturas e capítulos de que en la dicha carta se fasía minçión, non las auían visto nin fyrmado el rey, nuestro sennor. E que tanto que su altesa las viese y fyrmase, que luego las trahería a la dicha çibdad. E los dichos asystente e ofiçiales, visto lo sobredicho, dixeron que estaua bien que asy se fisiese" (Archivo Municipal de Sevilla (AMS), Sec. 10, carpeta 88, f. 2, 3r). La carta aludida es una que el trajo, firmada 
a Andalucía ${ }^{6}$. A partir de este momento, se centralizaron en Sevilla todas las gestiones realizadas por el citado triunvirato, al menos con las ciudades y territorios del Reino de Sevilla, como refleja la documentación de Carmona, Écija o Jerez de la Frontera. Esta fase culminó a comienzos de julio, antes de que los diputados marcharan a la Junta General de Madrid. Meses más tarde, la misma operación tuvo lugar en Córdoba, pues en noviembre los monarcas confirmaron el asiento establecido por el tesorero con los representantes del concejo cordobés ${ }^{7}$. Tanto en Sevilla como en Córdoba los monarcas, que estaban residiendo en ambas ciudades en los momentos en que se llevaron a cabo las negociaciones, intervinieron directamente en ellas.

Fruto de dichas negociaciones fue el establecimiento de una serie de asientos entre los diputados generales y los concejos, con los cuales, por un lado, se pretendió cerrar la etapa anterior en lo que se refiere a las deudas que cada uno de ellos venía arrastrando desde su incorporación a la Hermandad y, por otro, definir las condiciones de su vinculación a ella, sus contribuciones y los mecanismos de recaudación para el próximo trienio, el cual se abría a partir del 15 de agosto de 1478 .

Mientras que para la mayor parte de las localidades la información disponible es escasa, en Sevilla, al haberse conservado parte de las actas capitulares, sobre todo las correspondientes a los meses de junio y julio, es posible seguir a grandes rasgos el proceso de negociación ${ }^{8}$. La primera referencia se encuentra en el acta de la sesión capitular del 8 de junio, a la que acudieron Alfonso de Quintanilla y Juan de Almaraz. Según esta, los citados se habían estado reuniendo con los diputados locales de la Hermandad, lo que sitúa el comienzo de las negociaciones en el mes de mayo, y ahora solicitaban que el cabildo nombrase una comisión para que, conjuntamente, viesen las cuentas pasadas y estudiasen la financiación de los próximos tres años. Hicieron la advertencia de que si no respondían con prontitud a dicha solicitud sería el propio monarca quien la nombrase. De inmediato, se procedió a elegir una serie de capitulares, quienes se retiraron a otra habitación y una vez acordada por ellos su composición, volvieron a la sala capitular, donde se ratificó con algún voto en contra. Los propuestos fueron los regidores Luis de Tovar, García Tello y Fernando de Abreu y el bachiller Luis Sánchez, como

por los diputados de varias ciudades, cuyo contenido no está claro, al desaparecer la mitad del texto, no obstante, parece que se trata de una carta de creencia.

6. "A este cabillo veno don Juan de Ortega, prouisor de Villafranca, y mostró a los dichos asystente y ofiçiales vn poder que la Junta General de la Hermandad le auía dado para resydyr en la dicha Hermandad con los otros generales y diputados della. El qual visto, y lo quel dicho prouisor dixera sobre este negoçio, dixeron que verían en todo y farían lo que más a seruiçio del rey e reyna, nuestros sennores, cumplidero fuese" (AMS, Sec. 10, carp. 88, f. 3v).

7. Archivo General de Simancas (AGS), Registro General del Sello (RGS), 147811, nº 95. Apéndice $\mathrm{I}$.

8. Se encuentra descrito en J.M ${ }^{\mathrm{a}}$ Navarro Sáinz. “Aproximación al estudio de la Hermandad General bajo los Reyes Católicos en Sevilla y su tierra (1477-1498)", Historia, Instituciones, Documentos, 33, 2006, p. 467 y ss. 
letrado, a los cuales los capitulares añadieron dos jurados, Gonzalo Cerezo y Francisco de Alfaro.

Como habían expresado en la citada sesión, dos días más tarde, volvieron Alonso de Quintanilla y Juan de Almaraz para solicitar que, además de los ya nombrados, se ampliase la comisión con una serie de caballeros, por lo que los capitulares designaron al tesorero Luis de Medina y Alfonso Pérez Martel, veinticuatros, y a Juan de Pineda, escribano mayor del cabildo y de la Hermandad ${ }^{9}$. Las deliberaciones entre las dos partes duraron hasta el 22 del mismo mes, plazo en el que tuvieron tiempo para fijar los mecanismos de financiación e incluso consultar con el monarca. El citado día, ahora los tres diputados generales, acudieron de nuevo al cabildo. Explicaron que se habían reunido con los designados por la ciudad, y que, con ellos, auían entendido qué otra forma se ternía cómo esta Hermandad durase y el rey, nuestro sennor, fuese seruido y esta dicha çibdad non padesçiese, segund fasta aquí auía padesçido ${ }^{10}$. Fruto del citado acuerdo debió ser la firma de un asiento -que no he localizado-, al cual se refieren los monarcas en una carta fechada cuatro días más tarde, el 26 de junio ${ }^{11}$. El 6 de julio los tres diputados expusieron en el cabildo las gestiones que se habían realizado, y cómo querían que Alemán Pocasangre, mayordomo del concejo, actuase como tesorero junto con Juan de Lugo ${ }^{12}$. Finalmente, al día siguiente, en vísperas de su marcha a la Junta General de Madrid, presentaron en el cabildo otro asiento en el que se fijaban las obligaciones económicas de la ciudad y de su tierra, así como las remuneraciones de diversos servicios y funcionarios, destino de multas y ejecuciones, el cual se aprobó sin debates ${ }^{13}$.

Por lo que respecta a Jerez de la Frontera, las negociaciones debieron comenzar también en mayo, pues aunque no se conservan las actas anteriores al mes de junio, una carta de los reyes fechada el 25 de mayo daba respuesta a una demanda importante de los jerezanos, la de poseer provincia propia. Es posible que a raíz

9. AMS, Sec. 10, carp. 86, f. 10v-11r.

10. AMS, Sec. 10, carp. 86, f. 24r.

11. "E porque esta dicha çibdad fiso çierto asiento e conçierto con don Juan de Ortega, prouisor de Villafranca, e con Alfón de Quintanilla, nuestro contador mayor de cuentas e del nuestro Conçejo, e con Juan de Almarás, regidor e diputado de la çibdad de Salamanca, e Rodrigo de Sotomayor, fiel e diputado de la noble çibdad de Córdoba, en nombre e por poder que tienen de la dicha Hermandad, de la gente que esa dicha çibdad deue e le cabe a pagar para la dicha Hermandad. En el qual dicho asiento e conçierto fue por vos platicado cómo en la dicha çibdad se han fecho e fasen muchos repartimientos, asý los que por esa çibdad fueron repartydos por el çerco de la fortalesa de la villa de Vtrera, como para otras nesçesidades que esa dicha çibdad ha tenido e tiene, e se repartyó los maravedís que monta la dicha Hermandad desde el tiempo que por vos fue resçebida fasta oy, e se ha repartydo el pedido de la plata, que nos agora mandamos repartyr, en tal manera que los vesinos desa dicha çibdad non han acabado de pagar los dichos repartimientos..." (AGS, RGS, leg. 147806, $\mathrm{n}^{\circ} 128$ ).

12. AMS, Sec. 10, carp. 86, f. 39r. Respecto a Alemán Pocasangre, un mes antes, el 6 de junio, se había firmado en su casa un asiento con el concejo de Écija, aunque no se dice que fuese tesorero.

13. AMS, Sec. 10, carp. 86, f. 40-43. Apéndice VI. El documento va firmado solo por Alfonso de Quintanilla, tanto en los folios correspondientes a la ciudad como a los de la tierra, cuya rúbrica figura al pie de cada uno de ellos. Al dorso del último, el escribano del concejo dejó constancia de que el citado se llevó consigo una copia. 
de la mencionada carta se firmase un asiento, que tampoco he podido localizar ${ }^{14}$. Tras ella, siguieron las negociaciones, pues se conserva un memorial sin fecha, en el que el concejo envió instrucciones a los delegados que estaban negociando en Sevilla con los diputados generales ${ }^{15}$. Aparte de esto, pocos días antes de la firma del asiento conservado, se habían remitido documentos para apoyar su postura, a juzgar por un apunte que aparece inmediatamente antes del acta del 18 de junio, en el cual se dice: Aquí el memorial de todas las escripturas [...] que lleuó Pedro Camacho sobre la Hermandad ${ }^{16}$. Precisamente, el citado 18 de junio se firmó el asiento que puso fin a los debates sobre las deudas con la Hermandad y fijaba su contribución y forma de pago para el próximo trienio ${ }^{17}$.

En Carmona, el acta capitular del primero de junio da cuenta de que sus delegados enviados a Sevilla traían unos capítulos de la Hermandad, los cuales debía aprobar el cabildo y devolverlos a aquella el jueves siguiente ${ }^{18}$. Dada la coincidencia de fechas con las gestiones de otras ciudades, debe tratarse de las conversaciones previas a la firma de un asiento, al que, por otro lado, se alude en el encabezamiento de la cuenta de gastos del primer año de la prórroga:

Librança para la Hermandad de la ygualança que se fizo con los diputados de la dicha Hermandad por Ferrando de Párraga, regidor, en nombre desta villa por los tres annos venideros, desde Santa María de Agosto deste anno de lxx viijo en adelante, a preçio cada vn anno de dosyentas e veynte mill mrs. cada vn anno ${ }^{19}$.

Menos información hay sobre Écija, de la que solo se conserva el asiento para liquidar las deudas acumuladas, datado el 6 de junio. Es posible que por esas fechas también se negociara el que la ciudad tuviese un provincial y diputado, a juzgar por una referencia que aparece en un documento de Carmona, así como su contribución para el próximo trienio, al igual que ocurrió en las restantes ciudades ${ }^{20}$.

14. Es lo que se deduce de un párrafo del asiento que se incluye en el Apéndice: "segund se contiene en los capítulos e que con los dichos veynte e quatro e jurado, los dichos sennores diputados generales fesieron e asentaron, que está asentado en el libro del dicho Alfonso de Quintanilla, e pasó por ante el dicho Alfonso Sánches, secretario de la dicha Hermandad" (Apéndice V).

15. Es posterior a la citada carta, porque se hace referencia a una disposición regia sobre la cuestión de la provincia.

16. Archivo Municipal de Jerez de la Frontera (AMJF), Act. Cap., 1478, f. 19r. La fecha del citado apunte debe ser de dos o tres días antes, pues por esas fechas las reuniones capitulares se realizaban en plazos de dos o tres días e, incluso, en días seguidos.

17. Apéndice V. Curiosamente, el citado asiento no fue presentado al cabildo, al menos durante todo el mes de junio.

18. "Dieron su enbaxada Ferrando de Párraga, regidor, e Rodrigo de Villalobos, jurado, sobre la Hermandad de Seuilla. E fueron leýdos vnos capítulos que traxeron de allá, los quales han de boluer a el jueues. Dieron cargo para responder a los capítulos e hordenar la suplicaçión e escrituras a Alonso Yánnes e a Ferrando de Párraga, regidores, e a Rodrigo de Villalobos, jurado. Cargo a Ferrando de Párraga, regidor, para que vaya a la dicha junta el dicho jueues con las dichas escrituras e con otras, sy menester fuere, para el rey e reyna, nuestros sennores." (Archivo Municipal de Carmona [AMCa], Act. Cap., 1478, caja 4, f. 281v).

19. AMCa, caja 1.481 .

20. AMCa, caja 5, f. 229-230. 
Como señalaba al comienzo, una de las finalidades del desembarco de los delegados de la Hermandad fue resolver los problemas económicos que su financiación venía arrastrando desde el año precedente. El ordenamiento surgido de las Cortes de Madrigal estableció las bases de la misma: por una parte, en cada ciudad existiría un arca de la Hermandad; por otra, serían los concejos los que se hiciesen cargo de los gastos ${ }^{21}$. Pero desde los primeros momentos se observa la dificultad de poner en práctica dicha medida, a pesar del interés e incluso de la presión de los monarcas, como queda de manifiesto en un libramiento del concejo de Sevilla a su mayordomo, a mediados de junio de 1477:

Vos fue mandado por la dicha çibdad que de los dichos maravedis diésedes al dicho Melchior Maldonado veynte mill mrs. que ovo de aver por capitán de çient roçines que por la dicha çibdad con él fueron enbiados a la dicha sennora reyna por la Hermandad. E asý mismo, vos fue mandado que diésedes a çiertas cosas e gastos de la dicha Hermandad fasta en contía de dies mill mrs., segund que vos fuese mandado por qualesquier diputados de la dicha Hermandad.

Tras aludir a otros gastos generados por la citada operación y evaluar el total de la deuda generada por la Hermandad en 63.000 mr., continúa:

los quales auedes de reçebyr de los primeros maravedís que se repartieren e cogieren para la dicha Hermandad [...]. E por esta nuestra carta mandamos al thesorero e otras qualesquier personas que reçibieren e cobraren e touieren qualesquier maravedís por la dicha Hermandad, que de los primeros maravedis della vos den e paguen los dichos sesenta e tres mill mrs., pues se pagaron por la dicha Hermandad ${ }^{22}$.

Es decir, en ese momento la institución carecía de recursos y el mayordomo le adelantó un dinero, que luego debería ser reembolsado por el tesorero. La cuestión era que quienes habían ordenado adelantar el dinero - los capitulares- eran quienes tenían que haber acordado la fórmula de financiación, algo que no habían hecho, según se deduce del texto. Es más, el citado libramiento termina dirigiéndose a los contadores del concejo con la siguiente indicación: $E$ de oy en dos meses primeros siguientes se ynformen sy vos fueron pagados los dichos sesenta e tres mill mrs. de la dicha Hermandad. E sy nos vos fueron pagados, vos los reçiban asý mismo en cuenta ${ }^{23}$.

Dado que la incorporación de Sevilla a la Hermandad había tenido lugar en los meses de abril o mayo de 1477, a finales de junio aun no se había establecido el mecanismo de financiación, pues a tenor de las frases dirigidas a los contadores,

21. R. Carande, J. de M. Carriazo. El Tumbo de los Reyes Católicos del concejo de Sevilla, t. I, Sevilla, 1968, p. 280. Un dato importante a tener en cuenta es que les dejaba las manos libres, como se reafirmó en numerosos documentos posteriores, para decidir los procedimientos de recaudación sin necesidad de aprobación regia.

22. AMS, Sec. 15, $\mathrm{n}^{\circ} 7.161$.

23. AMS, Sec. $15, n^{\circ} 7.173$. Si bien, como se acaba de ver, en este documento los 100 caballeros se asignan a la Hermandad, en la carta de la reina en que efectúa la petición inicial de 350 efectivos no cita para nada a la Hermandad, sino que se dirige al concejo de Sevilla (AMS, Sec. 15, nº 7.161). 
los capitulares sabían que la citada devolución era inviable. Para complicar más la cosa, dado que dicha financiación tenía que venir de la mano de ingresos extraordinarios, pues los propios y rentas concejiles no daban para tales gastos, los capitulares hubieron de recurrir a repartimientos e imposiciones para hacer frente a los mismos, pero unos y otras constan como ingresos y gastos del concejo y no de la Hermandad. Así, en las cuentas municipales correspondientes a los ejercicios económicos de 1476-1477 y 1477-1478 no hay referencias a ingresos asignados a la Hermandad, pero sí ingresos y gastos para operaciones militares que fueron realizadas por las tropas de la institución ${ }^{24}$.

Cualquiera que fuese el procedimiento, más pronto o más tarde, los restantes concejos fueron habilitando recursos para su funcionamiento. Recursos que tuvieron siempre carácter extraordinario, pues, como en Sevilla, los propios y rentas municipales no podían hacer frente a dichos gastos. Los mecanismos puestos en marcha fueron muy variados. Quizás al que más se recurrió, a juzgar por diversos comentarios, fue al repartimiento entre los vecinos; pero también se crearon imposiciones o sisas ${ }^{25}$, o se aprovecharon algunas ya existentes para dirigirlas hacia este nuevo destino, como ocurrió en Jaén y Jerez de la Frontera ${ }^{26}$; en Úbeda, en los últimos meses del año 1477 se vieron obligados a vender solares para pagar, entre otras cosas, la Hermandad; finalmente, también se recurrió al crédito, aunque se reembolsaba con imposiciones o repartimientos ${ }^{27}$.

También es cierto que tan pronto como arbitraron los mecanismos recaudatorios comenzaron los rechazos de los afectados. En Córdoba, en los meses de agosto y septiembre de 1477, un elevado número de comerciantes y artesanos protestaron por las sisas que se les habían impuesto; un año más tarde, los que se negaron a pagar fueron los caballeros y otras personas ${ }^{28}$. Esas resistencias junto con las dificultades para encontrar los medios de financiación más adecuados motivaron que las deudas comenzaran a acumularse. Desde luego, la coyuntura no era la más propicia, debido a la dureza de los tiempos y al contexto fiscal en que se demandaron. Tras el cobro del pedido de 1476, cuyo importe se había incrementado considerablemente con relación a los precedentes ${ }^{29}$, a finales de $1477 \mathrm{se}$ estaba recaudando el denominado pedido líquido de 1475, que se había aplazado ante la coyuntura política ${ }^{30}$, más la parte del servicio recaudada en monedas e incluso la moneda forera ${ }^{31}$; luego, en 1478 , el pedido para el rescate de la plata

24. AMS, Sec. 10, carp. 86, fol. 24v. Sec. 15, 1476-1477, 1477-1478.

25. En octubre de 1477 los monarcas otorgan licencia al concejo de Carmona para echar sisas en el pan, vino, pescado, carne, leña, fruta y otros artículos (AGS, RGS, leg. 147710, $\mathrm{n}^{\circ} 160$ ) y en marzo de 1478 se alude a imposiciones sobre paños, lienzos y otras mercancías (AMCa, Act. Cap., 1478, caja 4, f. 222r, 224v, 310r).

26. AGS, RGS, leg. 147705, $\mathrm{n}^{\circ} 176$; leg. 147710, $\mathrm{n}^{\circ} 79,2$.

27. AMCa, Act. Cap., 1477, caja 4, f, 82.

28. AGS, RGS, leg. 147708, $\mathrm{n}^{\circ} 363 ; 147709, \mathrm{n}^{\circ} 554 ; 147806, \mathrm{n}^{\circ} 77$.

29. M.Á. Ladero Quesada. La Hacienda Real de Castilla en el siglo XV, La Laguna, 1973, p. 214

30. Se trataba del aprobado por las Cortes en 1473 (R. Carande, J. de M. Carriazo. El Tumbo..., t. II, Sevilla, 1968, p. 127-129. AMCa, Act. Cap., 1477, f. 109).

31. Ante la presentación de un libramiento a favor del despensero de los reyes, los capitulares de Carmona expusieron que el pedido líquido de 1475 les había supuesto $277.000 \mathrm{mr}$., los dos pedidos y 
de las iglesias; por otro lado, estaban las urgencias de la guerra de sucesión y con Portugal. A todo ello hay que sumar las necesidades locales, como los habituales pagos de salario de los asistentes o corregidores, obtenidos generalmente por medio de ingresos extraordinarios, pues debido a lo elevado de su montante no podía ser asumido por los ingresos ordinarios, así como los gastos en la defensa de la frontera que esgrimieron los concejos de Jaén y Jerez de la Frontera, o los realizados por Sevilla con ocasión de la llegada de los reyes ${ }^{32}$, o los atrasos de pedidos y monedas de años precedentes, como ocurría en Écija ${ }^{33}$, etc.

La consecuencia de todo ello fue una situación de deuda de los concejos con la Hermandad, que acabó convirtiéndose en permanente. En junio de 1478 varios jurados de Carmona denunciaron que no se había pagado a los caballeros de la Hermandad, por lo que estos podían abandonar el ejército, lo cual iba en deservicio del rey y podía generar perjuicios, daños y costes a la ciudad ${ }^{34}$. A finales del mismo año, Sevilla reconocía que debía 500.800 mr., de los cuales 100.000 correspondían a deudas de caballeros y regidores y el resto a villas y lugares de su alfoz $^{35}$. Según el asiento de Jerez de la Frontera las deudas acumuladas se cifraron en $155.800 \mathrm{mr}$., y en el de Écija, en $150.000 \mathrm{mr}$, que era lo que montaba lo que se había dejado de abonar por distintos conceptos, especialmente de los salarios del capitán y del diputado provinciales ${ }^{36}$.

Con independencia de que una parte de esa morosidad se debiese al rechazo de determinados colectivos a participar en los gastos, la realidad es que la presión había sido muy alta, como se reconoció de forma directa o indirecta por parte de los diputados generales en el proceso de negociación de los asientos. Quizá donde dicho reconocimiento se manifestó de forma más explícita fue en Sevilla. En una de las intervenciones de los diputados generales en el cabildo se expresaron en los siguientes términos:

E después de muchas altercaçiones que entre ellos ouiera, asý porque esta çibdad fuese releuada de las lanças y cargo que fasta [aqui] tenía, cómo por que se quitasen las grandes costas que fasta aquí se auían fecho, auían acordado e determinado que la dicha çibdad pagase $j q^{\circ}$ cccU mr., asý para pagar el general y las otras

monedas de 1476, 182.000 mr., y los caballeros de la Hermandad, 240.000 mr. Luego añadieron, sin valorarlo, que habían tenido que pagar las tropas enviadas a Toro y Trujillo y la moneda forera (AMCa, Act. Cap., 1477, caja 4, f. 109 y ss.).

32. AMJF, Act. Cap., 1478, f. 13v. AMS, Act. Cap. 1477, carp. 82, f. 46v, 96v.

33. A finales de 1476, el concejo de Écija había llegado a un acuerdo con la hacienda regia por el que deberían pagar $350.000 \mathrm{mr}$. por los que debían del reinado de Enrique IV (Archivo Municipal de Écija (AME), carp. 427, $\mathrm{n}^{\circ} 21$ ). En febrero de 1478 los reyes autorizaban al concejo a echar sisas o imposiciones, debido a lo gravoso de los repartimientos (AGS, RGS, leg. 147802, n 104).

34. AMCa, 1478, caja 4, f. 281v, 282r.

35. AMS, Act. Cap., 1478, carp. 89, f. 56. A consecuencia de todas estas deudas, el tesorero Juan de Lugo fue encausado y hecho prisionero, implicándose el concejo en este conflicto entre la Hermandad y el tesorero, que duró bastantes meses. Todavía en septiembre de 1479 se decía que Sevilla debía al citado $289.000 \mathrm{mr}$. (AGS, RGS, leg. 147909, n 53), y en noviembre reclamaba al concejo las deudas pendientes (AMS, Sec. 10, carp. 92, f. 43v, 45, 46).

36. Apéndice II. 
costas de la Hermandad, que heran los alcalles e quadrilleros y letrado y escribano y las otras cosas a ella tocantes, que montaua más de cc l U mr., como para pagar fasta çinquenta e çinco lanças, que montaría el sueldo dellas en cada vn anno ${ }^{37}$.

También los monarcas se hicieron eco de esa realidad en una carta dirigida al concejo sevillano:

fue por vos mucho platicado cómo en la dicha çibdad se han fecho e fasen muchos repartymientos, asý los que por esa çibdad fueron repartydos para el çerco de la fortalesa de la villa de Vtrera, como para otras nesçesidades que esa dicha çibdad ha tenido e tiene, e se repartyó los maravedís que monta la dicha Hermandad, desde el tiempo que por vos fue resçebida fasta oy, e se ha repartydo el pedido de la plata, que nos agora mandamos repartyr, en tal manera que los vesinos desa dicha çibdad non han acabado de pagar los dichos repartymientos e han resçebido y resçyben grandes dannos de sus fasiendas e han estado e están en grandes fatigas, de forma que por repartymiento no podrán pagar los maravedis que asý montan e vos cabe a pagar de la dicha Hermandad. E platicado cómo se pudiese pagar syn faser el dicho repartymiento y con el menos danno que pudiesen, con deliberaçión fue acordado que nos deuíamos dar liçençia a esa dicha çibdad para que pudiese para ello arrendar e coger la renta e derecho del corretaje . $^{38}$.

Como se verá a continuación, en los tres asientos conservados al aludir a una rebaja en el número de lanzas o caballeros, que era el principal gasto que asumieron los concejos, se utilizaron argumentos que, indirectamente, venía a reconocer lo elevado de la presión a la que estaban sometidos los vecinos, entre otros, los servicios que ya se prestaban o la benignidad del monarca.

Prueba de la importancia de la citada morosidad y de la necesidad de resolverla, es que se firmase con el concejo de Écija un asiento destinado exclusivamente a poner fin a dicha situación, pues, según se indica en el preámbulo ${ }^{39}$, el problema se remontaba a los inicios -desde que por ella fue resçebida. Se firmó en Sevilla, en la casa del tesorero provincial Alemán Pocasangre, al estar Écija integrada en esta provincia. Dada la importancia del salario de los caballeros o lanzas, lo primero que se planteó fue el número de estas. Así se expone que aunque el concejo tenía asignado 45 lanzas, incluidas las cinco que correspondían al capitán general, duque de Villahermosa, y al contador mayor, Alfonso de Quintanilla, se le hacía gracia de no tener en cuenta diez de ellas mientras los reyes no decidieran sobre las mismas, por lo que las cuentas se hicieron sobre 35, que, al parecer, eran las que se venían financiando de hecho, al decirse en el documento que siguiesen contribuyendo con dicho número hasta el 15 de agosto. Además de lo que restaba de la citada paga hasta dicha fecha, debían parte de la del capitán y del diputado provinciales, más $150.000 \mathrm{mr}$. Con el argumento de que el rey quería mostrarse

37. Aunque en las actas conservadas no consta lo referente a la tierra de Sevilla, también se debió negociar por estas fechas, pues figura en el asiento, con un importe de $1.600 .000 \mathrm{mr}$.

38. AGS, RGS, leg. 147806, $\mathrm{n}^{\circ} 128$.

39. Apéndice II. 
magnánimo con el concejo como reconocimiento por los servicios prestados por los astigitanos, se rebajó la deuda hasta los $120.000 \mathrm{mr}$. A continuación el documento establece el mecanismo para saldarla. La mitad, 60.000 mr., se entregaría a los diputados generales en un plazo de veinte días para pagar al capitán y diputado provinciales. En el caso de no abonar dicha cantidad en el plazo indicado, quedaría sin efecto la rebaja. Los otros $60.000 \mathrm{mr}$. se entregarían al tesorero local para hacer frente a los gastos de la Hermandad cuando esta necesitase ayuda o socorro, pero en concepto de préstamo, debiendo reembolsar al citado las cantidades de las que se hubiese dispuesto. Al cumplirse los tres años de la prórroga, el rey y los diputados generales decidirían el destino de los $120.000 \mathrm{mr}$. Aparte estaban los sueldos de las 35 lanzas hasta el 15 de agosto, cuyo importe habría que sumar a la referida cifra. Saldada la deuda, el concejo de Écija quedaba exonerado de cualquier pena, deuda, etc. que tuviese pendiente.

Como se puede observar, en dicho asiento no se alude al futuro, que sí se trató en los restantes aquí incluidos, lo cual quiere decir que, además de este, se negoció otro, cuya existencia desconozco, pero del que hay noticias, pues en algún momento se debió fijar el número de lanzas y el montante de la contribución que tendría que aportar a partir de este año, al igual que ocurrió en otras ciudades. Según los repartimientos remitidos anualmente por la hacienda regia, Écija debía contribuir con $400.000 \mathrm{mr}$., que es la misma cantidad acordada a Jerez de la Frontera; dado que a esta se le asignaron 20 lanzas, cabe deducir que el número de los caballeros astigitanos sería similar. En cuanto a la mencionada cifra de la contribución, en un acta capitular figura la cantidad de $420.000 \mathrm{mr}^{40}$; es posible que en esta ciudad ocurriese como en Jerez de la Frontera y Sevilla, que el concejo tuviese que comprometerse a asumir la diferencia o todo lo que superase las cantidades establecidas en los acuerdos.

El asiento que se ha conservado de Jerez de la Frontera refleja mejor los problemas existentes a estas alturas de mediados de 1478, pues, por un lado, trató de poner fin a las deudas que se venían arrastrando -como el de Écija-, y, por otro, definió cual sería su contribución y su gestión para el próximo trienio. La negociación de esta ciudad aparece como la más compleja de las que he podido documentar, pues introdujo una reivindicación que consideraron previa a cualquier otro tema: la de poseer una provincia propia y no formar parte de la de Sevilla. El motivo de esta exigencia fue que los capitulares consideraron que la misma mermaba gravemente su independencia. La cuestión debió considerarse lo suficientemente seria por parte de los diputados generales, como para que los reyes tuvieran que intervenir y diseñar un modelo específico de integración en la Hermandad ${ }^{41}$.

Los monarcas comenzaron reconociendo dicha gravedad, y cómo parecía que el motivo principal de su rechazo era que los capitulares consideraban que sus caballeros no debían de servir a las órdenes del capitán de Sevilla. Para solventar el problema, establecieron que hasta el 15 de agosto siguieran como hasta ese momento,

40. AME, Act. Cap., 1479-XI-10, fol. 40.

41. Apéndice III. 
sirviendo a las órdenes del citado capitán, aunque aclarando que ello no implicaría ningún tipo de sujeción del concejo de Jerez de la Frontera al de Sevilla, y que, a partir de esa fecha, todas las tropas del Reino de Sevilla servirían bajo la bandera real y a las órdenes de un capitán designado por los reyes, sin que su vecindad tuviese valor alguno, ni la ciudad de la que fuese vecino pudiese tener autoridad sobre $\mathrm{el}^{42}$.

A continuación expusieron las razones por las que no podía tener provincia propia. En primer lugar, porque Jerez de la Frontera carecía de tierra o alfoz y todas las localidades de su entorno ya estaban integradas en la institución, y porque las que aun no lo habían hecho debían incorporarse a la provincia de Sevilla. Seguidamente, introdujeron un argumento económico: el elevado coste que implicaba tener la cabecera de una provincia, debido a lo gravoso del organigrama provincial $^{43}$, lo cual, dada la situación de Jerez de la Frontera, podía afectar al buen cumplimiento de sus servicios, en concreto, la contribución destinada al pago de sus caballeros. Pero, aunque no aceptaron la creación de una provincia, sí dotaron a la ciudad de un estatuto propio, al contar con un diputado general y no estar obligada a enviar representante a las juntas provinciales de Sevilla, ni a contribuir en los gastos del diputado provincial, ni de otros de la citada provincia. Sí mantendría esa vinculación en todo lo relativo a la persecución de malhechores y ejecución de la justicia.

En cuanto a las otras negociaciones con los diputados generales, un memorial enviado por los capitulares a sus delegados que estaban en Sevilla permite conocer la postura del concejo ${ }^{44}$. Gran parte del mismo lo dedicaron a las cuestiones económicas y, una vez más, en estrecha relación con el número de lanzas. En primer lugar, reconocieron deudas pendientes de los caballeros por importe de 155.800 mr., además, aludían a otros gastos motivados por el envío de nuevos contingentes. Pero trataron de no pagarlas, pues, aunque los delegados llevaban su importe, en notas marginales les dijeron que solo las abonasen si no había más remedio. Para justificar dicho impago esgrimieron los importantes servicios que la ciudad venía prestando en la defensa de la frontera, así como los gastos y pérdidas que de ello se derivaban. Se trata de un argumento muy reiterado a lo largo de la centuria ante cualquier demanda de la Corona.

Luego plantearon las cuestiones relacionadas con el asiento para el próximo trienio, comenzando por el número de lanzas, que estaba fijado en 39. Demandaron su reducción pues consideraban que dicho número era injusto ${ }^{45}$. El mismo se había basado en un padrón que, en su opinión, en ese momento ya no era válido, pues, a consecuencia de los citados servicios, habían abandonado la ciudad del orden de 500 o 600 vecinos; además, porque en el estaban incluidos clérigos,

42. Ya en el mes de marzo, al cumplirse el tiempo del ejercicio del capitán de la provincia de Sevilla, la reina había enviado un representante suyo para indicarle al concejo que sería ella quien lo nombrase, lo que originó la oposición capitular (AMS, Act. Cap., 1478, carp. 85, f. 67v, 68).

43. En Sevilla, los citados gastos montaron 257.000 mr. (AMS, Act. Cap., 1478, carp. 86, f. 24).

44. Apéndice IV.

45. "Porque es çierto que sy a Seuilla dexaron quarto de caualleros, a Xeres deuen dexar meytad, segund los dichos seruiçios que ella fase e lo que en ellos cada vn día gasta" (Apéndice IV). 
frailes, hospitales e hidalgos, colectivos que ahora, precisamente, habían quedado exonerados de contribuir en los servicios de la Hermandad; finalmente, porque habían sido excesivos los gastos que habían tenido en el mantenimiento de todo el personal local de la Hermandad (alcaldes, diputado, escribanos, cuadrilleros, procuradores a las juntas, ballesteros, mandaderos, etc.). En consecuencia, solicitaron que el número de lanzas quedase en veinte. A cambio, ofertaron que el salario de cada una de ellas pudiese llegar a los $20.000 \mathrm{mr}$. anuales, siempre y cuando se respetase el acuerdo de que Jerez de la Frontera saliese de la jurisdicción de Sevilla. Si los diputados generales no estuviesen dispuestos a la citada rebaja, aconsejaron a sus representantes que les hiciesen ver cómo dichas lanzas serían servidas por personas del estado de los caballeros, con el fin de que el rey conociese el amor que la ciudad le tenía. Si nada de esto inclinaba a su favor la voluntad de los negociadores, indicaban a los delegados que les planteasen el envío de personas de su confianza, las cuales realizasen un nuevo padrón, con el fin de que se convenciesen de la situación real de los vecinos.

También solicitaron que el cabildo tuviese libertad para elegir el sistema de recaudación del servicio y que el contador Alfonso de Quintanilla entendiese en los distintos problemas que tenía planteada la ciudad, entre otros, que los clérigos pagasen lo que debían del repartimiento efectuado con anterioridad a que fuesen franqueados, para lo cual autorizaron a sus delegados a ofrecerle hasta $10.000 \mathrm{mr}$. En cuanto al servicio con el que debía de contribuir, hicieron una valoración negativa de su importe, al considerarlo superior a los pedidos y monedas anteriores, incluidos los demandados por estos monarcas, que ya habían sido más elevados, llegando a la conclusión de que era preferible volver a ellos ${ }^{46}$. Finalmente, requirieron a sus delegados que se entrevistasen con todas las personas que creyesen conveniente, entre ellas, con el ejecutor Pedro González de Hormisedo, así como con los diputados de Sevilla, para saber qué es lo que con ellos habían acordado, y que con toda esa información obrasen en consecuencia.

El asiento que cerró las negociaciones se firmó el 18 de junio de $1478^{47}$, y en el se concretaron las deudas, los gastos pendientes y la contribución para el próximo trienio. Respecto a las deudas, se valoraron en $125.000 \mathrm{mr}$. En dicha cantidad se incluía lo que restaba por pagar a las lanzas, especificándose que eran 36, más las tres destinadas al capitán general y al contador mayor, así como lo que se debía de diversos gastos a los que no se había hecho frente, entre ellos el sueldo del diputado y del capitán provinciales, en este caso, como consecuencia del ya mencionado conflicto con Sevilla. Se deduce de la justificación de la mencionada cifra, que se había hecho un descuento en compensación por los gastos de Jerez de la Frontera en la defensa de la frontera y las pérdidas que ello implicaba a los vecinos, con es-

46. Afirmaban que en tiempos de Juan II el pedido más alto fue de $150.000 \mathrm{mr}$., que sumado a las monedas hacían un total de 200.000 mr.; que los Reyes Católicos habían subido aquellos hasta 201.000 mr., más otros tantos de monedas, hasta alcanzar un total de $400.000 \mathrm{mr}$. Ahora, si se admitían los 20 caballeros, supondrían $400.000 \mathrm{mr}$, a lo que habría que sumar 100.000 de diversos gastos, lo que daría un total de $500.000 \mathrm{mr}$.

47. Apéndice V. No figura mención alguna al citado asiento en las actas del mes de junio. 
pecial mención en caballos, así como los que supusieron el envío de tropas para el cerco del castillo de Utrera, cuyo alcaide se había negado a entregarlo a los reyes. Con el abono de dicha cantidad, el concejo quedaba libre y exonerado de cualquier deuda, penas, etc., otorgándose carta de pago por el citado importe.

A continuación se estableció la cantidad con que la ciudad debía contribuir en el próximo trienio, la cual se fijó en $400.000 \mathrm{mr}$. anuales. Al indicar que se entregaría en Sevilla a los tesoreros Alemán Pocasangre y Juan de Lugo, se añadió una acotación en clara referencia a su reivindicación de provincia propia y separación de la de Sevilla: tesoreros de la Hermandad, puestos por los dichos rey e reyna, nuestros sennores, e por los dichos diputados en nombre de la Hermandad de los dichos reynos, e non por ser tesoreros de la paga de la dicha çibdad de Seuilla. De la mencionada cantidad, $10.000 \mathrm{mr}$. los retendría el concejo para hacer frente a los gastos de la Hermandad, por lo que se entregarían a los tesoreros, en Sevilla, $390.000 \mathrm{mr}^{48}$, repartidos en cuatro pagas: a finales de agosto y de noviembre de 1478, y a finales de abril y de mayo de 1479, y así en los dos años restantes. En caso de demora en el pago se le penalizaría con $1.000 \mathrm{mr}$. diarios. Dado que se consideraba que los citados $10.000 \mathrm{mr}$. no eran suficientes para cubrir los gastos locales, el concejo se obligaba a suplir lo que faltase.

Por lo que se refiere al asiento de Sevilla ${ }^{49}$, consta de dos partes: el referido a la ciudad y el del alfoz, y su contenido difiere de los dos precedentes, ya que se circunscribe a señalar el montante de la contribución de cada uno de ellos, y en qué se debía de invertir, con lo cual permite conocer el organigrama provincial. La ciudad aportaría $1.300 .000 \mathrm{mr}$. anuales y la tierra $1.600 .000 \mathrm{mr}$. Como no podía ser de otro modo, el grueso estaba destinado al pago de las lanzas que en la ciudad fueron 50 y en la tierra 80, a razón de $18.000 \mathrm{mr}$. por lanza y año, más las tres del capitán general, que se valoraron en 15.000 mr.; y las dos del contador mayor, que lo fueron en $17.500 \mathrm{mr}$. En el apartado de la ciudad se señala que el salario de los escuderos se habría de acordar con ellos, pero sin superar la cantidad menciona$\mathrm{da}^{50}$. Además se añade que en ella se incluían sueldos, acostamientos y pérdidas de caballos. El salario de los diez espingarderos que pagaba la tierra se estableció en $12.000 \mathrm{mr}$., lo que hacía un total de $120.000 \mathrm{mr}$.

En cuanto al organigrama provincial y las cantidades asignadas a cada oficio o función, fueron los siguientes:

- Dos alcaldes, uno caballero o escudero y otro ciudadano o pechero, que recibirían respectivamente 20.000 y $10.000 \mathrm{mr}$. En total, $30.000 \mathrm{mr}$. Además, para gastos de desplazamiento cuando fuesen a recorrer la tierra o alfoz se le asignaban al alcalde del estado de los caballeros y escuderos $4.500 \mathrm{mr}$., y al de los ciudadanos y pecheros $3.000 \mathrm{mr}$.

48. El desconocimiento de este dato es lo que hizo que, en su momento, al utilizar la documentación de la administración central, indicase que la contribución de Jerez era de 390.000 mr. y no de $400.000 \mathrm{mr}$.

49. Apéndice VI.

50. Luego, al fijar la cantidad que debía recibir el contador mayor por sus dos lanzas, señala que estas se valoraron como dos lanzas de escuderos, a razón de $17.500 \mathrm{mr}$. cada una. 
- 13 cuadrilleros, más un cuadrillero mayor, que percibiría 2.000 mr., mientras que el salario de aquellos sería de $1.000 \mathrm{mr}$. cada uno. En total 15.000 mr. Como, además, desempeñaban la función de correos, cobrarían 30 mr. diarios, cuando realizasen dicho cometido, para lo cual se destinaron $10.000 \mathrm{mr}$. Cada collación, de forma rotativa, designaría un cuadrillero y sería responsable de que estuviese siempre disponible.

- Un ejecutor provincial, $10.000 \mathrm{mr}$., más un porcentaje de 40 al millar por ejecuciones hasta $5.000 \mathrm{mr}$, a partir de esta cantidad solo podría percibir un máximo de $200 \mathrm{mr}$.

- Los letrados -no indica número-, $12.000 \mathrm{mr}$. De ellos, $6.000 \mathrm{mr}$. a los que de forma habitual asesorasen a los alcaldes, nombrados por los diputados general y provincial. Los otros $6.000 \mathrm{mr}$., a los que los alcaldes recurriesen en demanda de consejo.

- Un diputado general, 108.000 mr., que incluía su estancia en la Diputación General y los desplazamientos a la misma o a su casa desde ella, a razón de $300 \mathrm{mr}$. diarios. El diputado debería ser aceptado por el rey y por la Diputación General.

- Los dos tesoreros provinciales percibirían $20 \mathrm{mr}$. al millar por la gestión de lo que correspondía a la ciudad y a su tierra, por lo que el total de su remuneración ascendía a $58.000 \mathrm{mr}^{51}$.

- Un diputado provincial, $20.000 \mathrm{mr}$.

- Un capitán provincial 50.000 mr., más 1.000 mr. por cada lanza de la tierra, que eran $80.000 \mathrm{mr}$.

- Cinco lanzas para el capitán general, al precio de $15.000 \mathrm{mr}$. En total, $75.000 \mathrm{mr}$.

- Dos lanzas para el contador mayor, al precio de $17.500 \mathrm{mr}$. En total, $35.000 \mathrm{mr}$.

- Un escribano, designado por el escribano titular de la Hermandad, $15.000 \mathrm{mr}$., más $2.000 \mathrm{mr}$. cuando acompañase a los alcaldes en sus visitas a la tierra.

- Un carcelero, $1.500 \mathrm{mr}$.

Con relación al número de las lanzas de la ciudad, hay que señalar que debió producirse una reducción considerable, a tenor del comentario que se hizo por los regidores jerezanos, quienes afirmaron que a Sevilla se le había rebajado a la cuarta parte. Por otro lado, en el acta del 22 de junio, Alfonso de Quintanilla menciona la cifra de 55 lanzas. Salvo que se tratase de un error del escribano, la citada cifra no concuerda con la del asiento, por lo que se puede entender que no estaba cerrado este apartado de la negociación. La cuestión es que tampoco se indicaba si en la mencionada cifra estaban incluidas las del capitán general y del contador mayor.

51. Este concepto no se reguló en las otras ciudades, lo que se constituyó en una fuente de conflictos (AMCa, caja 5, f. 180r, v), ya que al quedar fuera de los asientos, fue una carga más que se echó sobre las arcas concejiles, al no poder pagarse con cargo a las contribuciones asignadas. Para Écija y Jerez de la Frontera suponía 6.000 mr., pues, a diferencia de Sevilla, los derechos eran los habituales de 15 al millar. 
Por otro lado, como se ha podido ver, los gastos del organigrama provincial corrieron a cargo de los vecinos de Sevilla, pues los de la tierra solo contribuyeron al de las tropas. Teniendo en cuenta la posible variación de los sueldos de las lanzas de escuderos, el total de los gastos fijos de la ciudad ascendieron a 1.317.000 $\mathrm{mr}^{52}$, superando, por tanto, la contribución fijada inicialmente. Según el asiento, el citado desfase se cubriría con el importe de las penas que se impusiesen. Respecto a la tierra, de los $120.000 \mathrm{mr}$. que montaba el sueldo de los espingarderos, solo contribuía con 50.000, por lo que el resto se cargaba a las restantes localidades de la provincia, a pesar de los cual, la cifra de gastos superaba en $2.000 \mathrm{mr}$. la fijada como contribución, y dicha diferencia debía salir también del resto de la provincia o de lo que se ahorrase en el sueldo de los escuderos.

Volviendo al montante del organigrama, este suponía un total de $257.000 \mathrm{mr}$, descontando no solo el importe de las 50 lanzas, sino también las del capitán general y contador mayor, lo que representaba el $19^{\prime} 5 \%$ de lo que la ciudad contribuía a la Hermandad.

La existencia de estos asientos confirma la complejidad que supuso el establecimiento de la Santa Hermandad y la pluralidad de intereses que incidieron en el proceso de aceptación de la misma. Lo cual hizo que, en el caso de las ciudades andaluzas, la integración fuese un proceso lento y complejo, de más de un año de duración, cerrado con las firmas de los mismos. A través de ellos, se pone de relieve que el problema económico tuvo una gran relevancia en dicho proceso y, en estrecha relación con él, el volumen de hombres que cada una debía aportar. De hecho, este parece que fue el apartado que más tarde se cerró, si es que alguna vez se cerró. También se puede observar cómo los diputados generales tuvieron que reconocer la carga excesiva que se había echado sobre los vecinos, al rebajar el número de lanzas o caballeros en los tres casos analizados. En este sentido, es esclarecedor el comentario de los capitulares jerezanos, que preferían volver a los pedidos y monedas, a pesar, incluso de que los últimos, aprobados en los inicios del reinado de los Reyes Católicos, eran más elevados que los anteriores.

Otro aspecto no menos importante es el del momento en que se cerraron los citados acuerdos. Se firmaron a renglón seguido de que se acordase la primera prórroga de la institución por tres años, quizá porque la inicial aparente provisionalidad de la misma contribuyó a que no se fijasen todos los aspectos de la pertenencia a ella de los concejos. En relación con esto, es muy significativo algo que, aunque no aparece en los asientos, se debió tratar paralelamente, como se deduce de las actas sevillanas ${ }^{53}$. Me refiero al hecho de clarificar cómo se podía hacer frente al pago de las cantidades acordadas, tanto por lo que se refiere a los mecanismos de recaudación, en los que se observa el predominio de las imposiciones

52. En el documento dice 1.322 .500 , lo que no se ajusta a la suma. Alguien se dio cuenta del error, porque en el margen anotó "j q $\mathrm{ccc}$ xvij U mr.".

53. C. López Martínez. La Santa Hermandad de los Reyes Católicos, Sevilla, 1921, p. 83 y ss. 
o sisas sobre los repartimientos, como en la tendencia a que se mantuviesen los mismos impuestos a lo largo de los años que estuvo vigente la Hermandad, como se observa en Sevilla y en Écija, donde se acuñó la expresión "sisas o imposiciones de la Hermandad" ${ }^{54}$.

A lo que no pudieron poner fin los asientos fue a la morosidad de los concejos, pues como lo acabado de indicar para los impuestos, esta fue una realidad que acompañó a la institución hasta su desaparición en 1498. La documentación municipal refleja meridianamente los constantes atrasos a la hora de hacer frente a los abonos de los diferentes plazos en que se debía hacer efectiva la contribución, así como las reclamaciones y los pleitos de los recaudadores y tesoreros.

Finalmente, estos asientos y su negociación plantean un doble interrogante: su relación, por un parte, con los pedidos precedentes $\mathrm{y}$, por otra, con los nuevos servicios de Cortes aprobados a partir de 1500, así como el hecho de que casi durante veinte años se mantuviese el mismo encabezamiento.

\section{APÉNDICES}

1478, noviembre, 13. Córdoba.

Don Fernando y doña Isabel confirman el asiento establecido por el provisor Juan de Ortega, en nombre de los diputados generales, y el concejo de Córdoba para el pago del servicio de la Hermandad por los tres años de la primera prórroga.

A.- Archivo General de Simancas, Registro General del Sello, 147811, nº 95.

Don Ferrnando e donna Ysabel, etc. Por quanto vos don Juan de Ortega, prouisor de Villafranca, nuestro sacristán mayor, dyputado vniuersal de las hermandades destos nuestros regnos de Castilla e de León, y por virtud del poder que tenedes del duque don Alfón, nuestro hermano, capitán general de las dichas hermandades e del reuerendo yn Xpo, padre obispo de Cartajena, presydente del nuestro Consejo e en la Diputaçión General, e de Alfonso de Quintanilla, nuestro contador mayor de cuentas e del nuestro Consejo e contador mayor de las dichas hermandades, e de los diputados generales de las dichas hermandades, e por nuestro mandado, ovistes fecho e fesystes yguala e convenençia con el conçejo, corregidor, veynte e quatro caualleros, jurados, escuderos, ofiçiales e omes buenos de la muy noble e leal çibdad de Córdoua, que diesen e pagasen en cada vn anno de los tres que la dicha Hermandad se asentó en estos nuestros reynos, que comiença desde el día de Santa María de Agosto que agora pasó deste presente anno fasta ser complidos para el seruiçio que la dicha çibdad ha de faser a la dicha Hermandad, asý de la gente de cauallo como de pie e otros qualesquier gastos e costas que a la dicha Hermandad de la dicha çibdad se recresçen en qualquier manera, dos cuentos e çinquenta mill mrs. Asý que son en los dichos

54. P. Rufo Ysern. "La fiscalité extraordinaire à Ecija à la fin du Moyen Âge: imposiciones et sisas”, en D. Menjot, M. Sánchez Martínez (coord.). La fiscalité des villes au Moyen Âge (occident méditerranéen. 2. Les systèmes fiscaux, Editions Privat, Toulose, 1999, p. 485-496. 
tres annos seys cuentos e çiento e çinquenta mill mrs., pagados en la forma e manera que en el dicho asyento e conveniencia e yguala que con ellos fesistes se contyene. Por ende, porque la dicha çibdad sea más segura que el dicho asyento valdrá e será firme e estable e valedero, por la presente lo aprouamos e confirmamos e avemos por firme e estable e valedero el dicho asiento e yguala e convenencia que asý con la dicha çibdad fesistes. E la avemos e avremos e tenemos e ternemos por buena e firme e estable e valedera para agora e sienpre jamás. E non yremos nin vernemos contra ella, agora nin en algún tiempo, nin por alguna manera, con tanto que la dicha çibdad aya de complir e cumpla el dicho asyento e yguala e convenencia, que asý con ellos fesistes, durante la dicha Hermandad por los dichos tres annos como dicho es. E mandamos al dicho conçejo, corregidor, veynte e quatro, caualleros, jurados, escuderos, ofiçiales e omes buenos de la dicha çibdad de Córdoua que luego fagan la obligaçión de lo susodicho, según e en la manera que con ellos está asentado por vos el dicho prouisor, e obliguen los bienes e propios del conçejo de la dicha çibdad, porque mejor se guarde e cumpla. E los vnos nin los otros non fagan ende al por alguna manera, so pena de la nuestra merced. Dada en la muy noble e leal çibdad de Córdoua, a trese días del mes de nouiembre, anno del nasçimiento de Nuestro Sennor Ihuxpo de mill e quatrocientos e setenta e ocho annos. Yo, el rey. Yo, la reyna. Yo, Fernand Daluares de Toledo, secretario del rey e de la reyna, nuestros sennores, lo fise escribir por su mandado. Registrada. Diego Sánchez.

\section{8-VI-6. [Sevilla].}

Asiento establecido por el concejo de Écija con los diputados generales de la Hermandad sobre el pago de las deudas generadas por el funcionamiento del año precedente

\section{A.- Archivo Municipal de Écija, caja 608, nº 38.}

Testimonio que se tomó en Sevilla del asiento de la yguala que se hiso por parte de don Furtado de Mendoça, justiçia mayor de Éçija, y Alfonso de Çayas, regidor y procurador mayor della. Anno de jU $\operatorname{cccc}^{\circ}$ lxx viij.

Testimonio del asiento de la iguala que se fiso por las penas e non seruido el anno primero de la Hermandad, c xxU mrs. Anno de jU $\operatorname{cccc}^{\circ} 1 \mathrm{xx}$ viij.

En la muy noble y muy leal çibdad de Seuilla, sábado seys días del mes de junio, anno del nasçimiento del Nuestro Saluador Ihuxpo de mill e quatroçientos e setenta e ocho annos. En este día, estando ayuntados en las casas de Alemán Garçía Pocasangre, que son en la dicha çibdad, en la collaçión de sant Saluador, de vna parte, los honrrados sennores Alfón de Quintanilla, contador mayor de cuentas del rey e reyna, nuestros sennores, y del su Consejo e contador de la Hermandad de los tres estados de Castilla e de León, y el reuerendo sennor don Juan Dortega, prouisor de Villafranca, y el honrrado cauallero Juan de Almarás, regidor e diputado de la prouinçia de Salamanca, diputados generales de la dicha Hermandad por virtud de los poderes que della tienen, e, de la otra parte, el sennor don Furtado de Mendoça, justiçia mayor de la noble y leal çibdad de Éçija, e Alfonso de Çayas, regidor e procurador de la dicha çibdad, en bos e en nombre de la dicha çibdad, por virtud del poder que della tienen, y en presençia de mi, Pedro Gonçales de Éçija, escribano del rey e de la reyna, nuestros sennores, e su notario público en la su corte y en todos los sus reynos e sennoríos, 
por amas las dichas partes fue altercado e platicado sobre rasón de las cosas a que la dicha çibdad de Éçija era obligada y encargada de seruir a la dicha Hermandad desde el día que por ella fue resçebida, segund las leyes e capitulaçiones por ella otorgadas e hordenadas, e de las otras cosas que çerca de aquello era mandada e obligada a faser e conplir, asý çerca de la gente de cauallo con que era tenida de seruir, como de la parte de la costa del capitán e diputado prouinçial. Y después de muchas plátycas e altercaçiones auidas, se asentó e acordó que de cuarenta e çinco lanças e más çiertos vesinos con que la dicha çibdad avía de seruir, segund el enpadronamiento que tenía, que al presente quedasen suspensas las dies lanças, y que destas dies lanças no se le fiziese cargo alguno, fasta ver e atender la voluntad y determinaçión del rey, nuestro sennor. Y que siruiese fasta el día de Santa María de Agosto con las treynta e çinco lanças que agora sirue, las treynta en caualleros, e las çinco que se le descuentan en esta guisa: las quatro para el sennor duque, capitán general, e la vna para el dicho Alfonso de Quintanilla, contador. Las quales çinco lanças ayan de pagar por rata, fasta el dicho día de Santa María de Agosto, a rasón de quinse mill mrs. por anno, syn otra costa alguna.

E vistas e conosçidas por los dichos sennores de amas partes las cosas que la dicha çibdad e sus caualleros avían de faser e conplir que non fizieron nin cunplieron, se falló que demás de las dichas diez lanças que al presente quedan suspensas, de que non se fase cargo, que montan en cada anno çiento e çinquenta mill, que la dicha çibdad era debdora e obligada a pagar otras çiento e çinquenta mill mrs. de lo que non avían seruido e conplido. Esto, demás de la parte que les cabía del capitán e diputado prouinçial. Lo qual estando asý, los dichos sennores diputados generales, conosçiendo la entençión e voluntad del rey, nuestro sennor, que es de se aver benignamente con la dicha çibdad, e le faser bien e merced, e siguiendo aquella, e por la gratyficar e tener más açebta, a seruiçio del dicho sennor rey e de la dicha Hermandad, y en emienda de los seruiçios que ha fecho y fase de cada día al dicho sennor rey, acordaron e mandaron de concordia que por emienda y entero pago y satisfaçión de todas las cosas que la dicha çibdad y los caualleros que por ella siruen a la dicha Hermandad eran e son en cargo fasta oy, asý de lo que no han seruido nin conplido, como de la parte que les cabía del salario de los dichos capitán e diputado prouinçiales, deuían e deuen pagar çiento e veynte mill mrs., en esta guisa: los sesenta mill mrs. a los dichos diputados generales, o a quien ellos mandaren, de oy fasta veynte días deste mes de junio en que estamos, para que dellos paguen e contenten e satysfagan a los dichos capitán de la prouinçia de Seuilla, donde cabe la dicha çibdad e siruen los dichos treynta caualleros, e asý mismo paguen al diputado prouinçial, e fagan las cosas que ellos vieren y entendieren que más cunple a seruiçio del dicho sennor rey, e a bien e pro común de la dicha Hermandad. Y que la dicha çibdad, si non cunpliere e pagare los dichos sesenta mil mrs. fasta el dicho día veynte deste mes, que non gose desta graçia e suelta que se les fase.

E los otros sesenta mill mrs. que la dicha çibdad los ponga en poder del tesorero de la dicha çibdad de Éçija, para que los tenga de manifiesto el tiempo de los tres annos que la dicha Hermandad está otorgada, para que de allí la dicha çibdad se socorra e ayude quando ouiere menester ser socorridos, prestados los dichos sesenta mill mrs. para el sueldo de su gente con que ha de seruir cada que la nesçesidad lo pidiere, torrnándolos sienpre al dicho depósito. Y en fin de los dichos tres annos, que la dicha çibdad sea tenuda e obligada de los dar a quien el dicho sennor rey e los diputados generales mandaren.

E demás desto, la dicha çibdad sea tenuda e obligada a conplir e pagar las dichas treynta e çinco lanças en la manera que dicha es, fasta el día de Santa María de Agosto primero que verrná. E pagados e depuestos por la dicha çibdad los dichos çiento e veynte mill mrs. en la manera e forma que dicha es, e cunpliendo e pagando las dichas treynta e çinco lanças, que non sea tenuda nin obligada a pagar mrs. algunos al capitán de la prouinçia nin al diputado. 
E sea libre e quita dello e de otras qualesquier cosas que fasta aquí non ayan conplido ella e los caualleros que por ella han seruido. E de qualesquier penas e calupnias, en que fasta aquí la dicha çibdad e caualleros ayan caydo e yncurrido en qualquier manera, o por qualquier causa o rasón que sea, o ser pueda o deua, quedando a saluo su derecho a la dicha çibdad contra los caualleros que cogió y pagó e tiene para el dicho seruiçio para cobrar dellos los mrs. y otras cosas a que le son obligados, asý de prinçipal como de penas, por no aver fecho e conplido enteramente las cosas a que se obligaron. Para todo lo qual faser y exsecutar, los dichos diputados generales, por mandado de los dichos rey e reyna, nuestros sennores, e por virtud del poder que han e tienen de la dicha Diputación General, dieron poder conplido a la dicha çibdad, e para faser e mandar faser qualquier repartimiento que para conplir e pagar lo susodicho fuere nesçesario.

Todo lo qual quedó asý asentado e acordado entre amas las dichas partes e otorgado, so pena quel que lo non cunpliere sea tenudo de pagar las costas e dannos a la otra parte.

El provisor (rubricado). Alfonso de Quintanilla (rubricado). Juan de Almarás (rubricado).

Yo, Pedro Gonçález de Éçija, escriuano del rey e de la reyna, nuestros sennores, e su notario público en la su corte y en todos los sus regnos e sennoríos fuy presente a todo lo sobredicho en vno con los dichos testigos, y vy firmar aquí sus nombres a los dichos diputados, e so testigo, e fise aquí este mío signo a tal?, en testimonio de verdad. Pedro González (signo).

III

\section{V.29.}

Los reyes responden a una petición del concejo de Jerez de la Frontera para tener provincia propia en la Hermandad y no estar integrada en la de Sevilla.

A.- AMJF, AHS, caja 3, nº 49, f. 6 r, v.

B.- AMJF, AHS, caja 3, no 49, f. 7 r, v. (firmado por Alfonso de Quintanilla).

Edit.- Joyas bibliográficas, VIII, Jerez, $n^{\circ} 5$. Privilegios y viejos documentos, Madrid, 1971.

El rey e la reyna. Por quanto en alguna diferençia que ay en la orden e gouernaçión de la Hermandad entre la muy noble çibdad de Seuilla e la noble çibdad de Xeres se nos podría seguir deseruiçio e danno e detrimento a la gouernaçión de los casos de la dicha Hermandad sy la dicha diferençia no se atajase. E queriendo prouer en ello como cumple a nuestro seruiçio, mandamos e declaramos que entre las dichas çibdades en los casos e seruiçios de la dicha Hermandad se guarde e tenga la orden que adelante será contenida, en esta guisa.

Quanto a la gente de cauallo que cabe a seruir a la dicha çibdad de Xeres, que desde aquí fasta el día de Santa María de Agosto primero syuan en la compannía e capitanía del capitán de la prouinçia de Seuilla, syn que por ello se entienda que la dicha çibdad de Xeres tenga más subgeçión a la dicha çibdad de Seuilla de la que tenía e touo en los tiempos pasados, antes que se ordenase e constituyese la dicha Hermandad. E que desde el dicho día de Santa María de Agosto en adelante todas las gentes que cupieren a seruir a la dicha Hermandad, asý a la dicha çibdad de Seuilla como a la dicha çibdad de Xeres e a todas las otras çibdades e villas e logares de su Arçobispado con el Obispado de Cádis, 
todas anden debaxo de nuestra vandera e con nuestro capitán que, por virtud de la dispusiçión de las leyes, avemos de poner e nombrar en la capitanía de los dichos Arçobispado e Obispado. E que non se entienda que el dicho capitán tiene ninguna preminençia en la dicha capitanía por ser vesyno de qualquiera de las dichas çibdades, sy lo fuere, saluo por beuir con otros o con qualquier de nosotros, e porque se le daua la dicha capitanía por nuestra mano. E que ninguna de las dichas çibdades, nin villas, nin logares non tengan sobre el tal capitán nin sobre las dichas gentes ninguna administración, saluo nuestras personas reales e la persona que para ello touiere nuestro espeçial mandado, por quanto esta es nuestra deliberada voluntad e asý cumple a nuestro seruiçio, e así lo declaramos e mandamos que se faga.

En quanto toca a lo que la dicha çibdad de Xeres pide, que sea cabeça de prouinçia, pues la dicha çibdad non tiene tierra alguna, e todas las otras que son en derredor e comarca della son entradas en la dicha Hermandad, e sy algunas están por entrar deuen entrar en la dicha çibdad de Seuilla. E porque nuestra merçed e voluntad es de escusar e quitar las cosas extraordinarias e demasiadas de las que son menester para las dichas gentes de cauallo que han de seruir. E sy la dicha çibdad de Xeres fuese cabeça de prouinçia, avría de tener diputado general e otras costas que se le syguirían, que buenamente se pueden escusar.

Por ende, es nuestra merçed e voluntad, e mandamos que la dicha çibdad de Xeres sea libre de venir nin enbiar a las juntas prouinçiales que de aquí adelante se fisieren en la dicha çibdad de Seuilla, e de pagar e contribuyr en la costa e gasto del diputado prouinçial, nin general, nin capitán, nin otras costas extraordinarias que se fizieren por la dicha çibdad de Seuilla e su prouinçia, eçebto la dicha gente que asý le cabe e cupiere, en la manera que dicha es, en el capítulo antes deste. E que quede libre e exsida en todas las cosas e costas de la dicha Hermandad de la dicha çibdad de Seuilla e su prouinçia, saluo solamente que tengan e guarden hermandad vnos con otros en la esecuçión de la justiçia e seguimiento de los ladrones e malfechores, e para los entregar de la vna juridiçión a la otra donde delinquieren, para que allí sean punidos e castigados, segúnd la orden e leyes de la Hermandad. E que la dicha çibdad de Xeres por sý sea tenuda de enbiar a las Juntas Generales de las Hermandades que se fizieren en estos nuestros reynos sus procuradores con poderes bastantes para consentir e otorgar las cosas que fueren ordenadas e por nosotros fueren confirmadas.

E es nuestra merçed e voluntad que en las costas pasadas fasta el día desta nuestra declaraçión, amas las dichas çibdades e vezinos e diputados e ofiçiales dellas pasen y estén por la declaraçión que en ello dieren don Juan de Ortega, prouisor de Villafranca, e Alonso de Quintanilla, nuestro contador mayor de cuentas y del nuestro Consejo, e Juan de Almarás, regidor e diputado general por la çibdad de Salamanca e su prouinçia. A los quales mandamos e cometemos que lo determinen como cumpla a nuestro seruiçio e a pacificación e conformidad de las dichas çibdades, como a ellos bien visto fuere, para lo qual les damos todo nuestro poder cumplido. Fecha, veynte e nueue días de mayo, anno del nasçimiento de Nuestro Sennor Ihuxpo de mill e quatroçientos e setenta e ocho annos.

Yo, el rey. Yo, la reyna.

Yo, Alfón de Auila, secretario del rey e de la reyna, nuestros sennores, la fise escriuir por su mandado.

(Al pie del folio) Concordia entre las çibdades de Seuilla e Xeres. 


\section{8.[VI]. [Jerez de la Frontera].}

Instrucciones del concejo de Jerez de la Frontera a sus delegados que trataban con los diputados generales de la Hermandad un asiento sobre sus deudas y su contribución.

A.- Archivo Municipal de Jerez de la Frontera, Actas Capitulares, 1478, fols. 13r-15v.

\section{Memorial}

Memorial de las cosas que los mandaderos de la çibdad de Xeres, Pedro Camacho de Villaviçençio, veynte y quatro, e Pedro Camacho, jurado desta dicha çibdad, han de faser e procurar en corte del rey nuestro sennor, con su altesa y con los generales de sus regnos, sobre el caso de la Hermandad, es lo que se sigue.

Lo primero, que den al rey e reyna, nuestros sennores, las petiçiones que para sus altesas lleuan.

Ýtem, asý mesmo, que den a los diputados generales la carta, que desta çibdad lleuan, sobre el caso de las hermandades.

Asý mesmo, que miren el poder que esta çibdad le dio a los dichos mensajeros, y con aquel se conformen.

Asý mesmo, lleuan los dichos mensajeros desta çibdad para pagar el sueldo de los caualleros por dos meses e veynte e ocho días, que començaron a dies e ocho días del mes de mayo, que agora pasó, e se cumplen el día de Santa María de Agosto, primera que viene, deste anno. Que fue el día que la reyna nuestra sennora los enbió mandar por su carta, que tornasen a seruir los treynta e seys caualleros, con que esta çibdad seruía la Santa Hermandad, a rasón de quinse mill mrs. por anno a cada cauallero. Que monta çiento e treynta e dos mill mrs. (Al margen) Desid que traeys sueldo por dos meses, e quando non pudierdes, aveys de declarar este capítulo.

Yten, avéys de desir al sennor Alonso de Quintanilla que su merçed mire que es lo que le deue esta çibdad del cauallero que le es obligado, de más de los çinco mill mrs. que tiene resçebidos de Juan de Ferrera. Y que aquello le queráys complir e pagar, como su merçed mandare, non mirando día de reçebimiento que esta çibdad aya fecho a la Santa Hermandad, nin otra cosa alguna. Para lo qual lleuáys en vuestro poder otros dies mill mrs. de vna cauallería entera, que era quinse mill mrs. (Al margen) Non le declarareys estos x U mr. fasta quel declare que le deueys x $\mathrm{U}$ mr.

Yten, avéys de desir al dicho sennor Alonso de Quintanilla que declare su merçed lo que es deuida esta çibdad a la sennora duquesa de Villafermosa, de las dos lanças que esta çibdad le es en cargo, fasta fasta (sic) Santa María de Agosto primera. Y que, en este caso, esta çibdad non quiere mirar con su sennoría el tiempo del resçibimiento de la Hermandad, saluo seruirle e pagar lo quel dicho Alonso de Quintanilla mandare. Y avéys de pagar a su merçed trese mill mrs, que son a complimiento de treynta mill mrs. que montan dos lanças de sueldo por vn anno, en esta manera:

- que resçibió de Juan de Ferrera x U

- que resçibió por su merçed Aluar Lopes vj U

- ítem, a Vruenna, paje del sennor duque de Villafermosa, dosientos mrs. cc

(Al margen) Non declareys lo que lleuays fasta que Alonso de Quintanilla vos declare lo que aveys de pagar. 
Y por que seáys ynformados de lo que asy lleuáys para pagar el dicho sueldo e a la duquesa e [a] Alonso de Quintanilla, son çiento e çinquenta e çinco mill e ochoçientos mrs. (Al margen derecho) $\mathrm{c} 1 \mathrm{v} \mathrm{U} \mathrm{dccc}^{\circ}$.

Y sabed quel día del resçebimiento que esta çibdad fiso a la Santa Hermandad con las limitaçiones de ser cabeça de prouinçia , y non en otra manera, fue a tres días del mes de jullio del anno de setenta e syete. Al qual resçebimiento fue presente Pedro del Algaua, que fiso la presentaçión dello, segund lo lleuays por fe del escribano.

Ítem, el reçebimiento segundo que la çibdad fiso a la Santa Hermandat fue con la mesma protestaçión, en xvj de octubre del dicho anno, quando sacó alcaldes y ofiçiales de Hermandat. Y asý va por fe.

Y por que podáys mejor desir lo que conuiene a esta çibdad, y a su descargo, fallarán los diputados que por carta suya fue mandado que esta çibdad enbiase en seruiçio de la Santa Hermandad los xxx vj caualleros con que ella era tenida a le seruir. La qual carta fue trayda e presentada y reçebida en esta çibdad en $\mathrm{xx}$ viij $^{\circ}$ de disiembre deste anno. E estos caualleros fuesen pagados por iiij ${ }^{\circ}$ meses, que començasen desde el día que partiesen. Y ellos partieron desta çibdad, sábado jx de enero de $1 \mathrm{xx}$ viij ${ }^{\circ}$. Cuyo traslado de carta lleuáys en vuestro poder.

Y en quanto al caso de las cuentas pasadas, de que a esta çibdad se fase cargo, en esto avéys de ynsystir, suplicando al rey, nuestro sennor, y a la reyna, nuestra sennora, sy la pudierdes ver, que sus altesas se ayan por seruidos desta çibdad con lo que fasta aquí la çibdad ha cumplido. Conformándovos con la petyçión que para sus altesas lleuáys, pidiendo lo que por ella pide la çibdad: que sean dados por libres e quitos de todo ello; poniéndoles delante los seruiçios de moros y xristianos y guardas y pérdida de cauallos e robos e otras cosas, que se remiten a vuestra discreçión. Porque la falta de lo pasado, esta çibdad suple en la demasýa que dará por cada lança que ouiere de pagar en los tres annos venideros.

Y esta mesma orden avéys de tener e pedir por merçed a los sennores diputados generales, segund que la çibdat ge lo pide por merçed por su carta.

Y en esto avéys de ynsystyr, e de aver fyn e quito y remisyón del rey e reyna, nuestros sennores, y de los sennores generales y de todo lo pasado, segund que por la petyçión desta çibdad, que para los reyes leuáys, se contiene y por el dicho poder se declara, el más bastante que se pueda ordenar.

Y veniendo en el caso del asyento que avéys de dar con los diputados generales para en el caso del encabeçamiento en que se ha de poner esta çibdad para los tres annos venideros, que comiençan desde Santa María de Agosto primera en adelante, avéys de guardar e mirar en ello todas estas cosas. Y aquellas miradas e guardadas, fased el asyento con los dichos generales.

Lo primero, que miren cómo esta çibdad, después de los padrones que se fisieron, por donde se fiso cargo de la encabeçar en xxx jx lanças, son ydos desta çibdad muchos vesinos della a toda esta tierra comarcana de los sennoríos.

Ítem, que miren que en este empadronamiento entraron los clérigos y fáblicas (sic) e ospitales e monasterios y frayles de orden.

Por manera, que faltarán más de quinientos o seysçientos vesinos y, demás desto, se han de sacar fidalgos.

Y más, que la çibdad ha fecho e fase costas en alcaldes y en diputados e en escribanos y en quadrilleros e en ballesteros e en mandaderías y en procuradores para la Junta General, y en otras cosas aças. Que, por ello, la mande boluer e encabeçar en veynte lanças. Y por aquello, vos acordar con los sennores diputados quánto pagaréys en cada anno, y darles ende? por cada cauallo de $\mathrm{x}$ viij $^{\circ}$ a xxU mrs., e non vna blanca más. Esto, guardándose a esta çibdad lo quel rey declaró e mandó con los dichos diputados çerca de ser sacada esta 
çibdad de la juridiçión e sogeçión e prouinçia e mando de Seuilla, e quedando por sý, como se contiene en lo capitulado, y non en otra manera. E que los maravedís que estos caualleros montaren en cada anno, que Xeres ge los pagará aquí en Xeres o en (blanco), por los terçios del anno. Y que otra cosa alguna esta çibdad non pague, nin sea obligada de pagar en ninguna manera, nin por ninguna cabsa nin rasón nin color, nin por leyes de Hermandad que son o sean fechas. Saluo solamente los dineros que montaren las dichas veynte lanças, al dicho presçio e en los dichos términos, como es dicho.

Ítem, que sy non quisyeren venir en estos xx caualleros al dicho preçio, desid que con ellos seruirá esta çibdad en caualleros, porque conoscan quanto quiere Xeres seruir a sus altesas del rey e reyna, nuestros sennores, y que esta es la últyma voluntad desta çibdat.

Ítem, sy non quisyeren creer el caso del agrauio que Xeres tyene en los dichos vesinos ydos, desid a su merçed de los generales que ellos, de su mano, enbíen aquí vna persona o dos para que, con otra o otras dos, empadronen toda esta çibdad. Y, fecho el empadronamiento, por allí verán cómo la çibdad dise verdad al rey, nuestro sennor, y a los dichos diputados.

Ítem, en el caso de ser pagados los maravedís que los dichos caualleros montan, esto ha de ser por derrama por esta çibdad o por vía de ynpusyçión, como esta çibdad entienda que más cumple al seruiçio del rey e reyna, nuestros sennores, e al bien desta çibdad.

Ítem, avéys de trabajar con los sennores generales e con Alonso de Quintanilla, cómo su merçed mande a los clérigos desta çibdat que paguen lo que les copo del repartymiento pasado, fasta Santa María de Agosto primera, porque fasta oy non han pagado cosa alguna.

Ítem, fablad con el sennor Alonso de Quintanilla que los fechos desta çibdad los endereçe e tome por suyos, e les dé la conclusión que esta çibdad pide e como al bien della cumple, porque en aquello el rey e reyna, nuestros sennores, son seruidos. Porque esta çibdat tyene tantos trabajos, que non se le pueden desir, y que como quier que sus trabajos non se le pagan, pero que esta çibdad le quiere onrrar e aprouechar en quanto pudiere. E para ello se remite a vos le prometays viij ${ }^{\circ} \mathrm{o}$ x U mrs., porque entendemos que esto conuiene mucho al bien de la çibdat. $O$ de aquí abaxo, lo que vosotros sennores viérdes.

Y sy, por caso, todavía ynsystieren estos sennores diputados de todavía pedir más número de caualleros de Santa María de Agosto en delante de los xx caualleros que ya son dichos, desid que en tiempo del rey don Juan tenía Xeres cabeça de mayor pedido c $1 \mathrm{U}$ mr., e con las monedas montaua cc $\mathrm{U}$ mr., e que después, el rey e reyna, nuestros sennores, nos encargaron de cc i U mr. de pedido, e con las monedas serán otros tantos, que son $\operatorname{cccc}^{\circ} \mathrm{U}$ mr. Pues mejor sería pagar pedido e monedas, que non pagar más número de caualleros de los dichos veynte caualleros, que montan $\mathrm{cccc}^{\circ} \mathrm{U}$ mr., y de otras costas más de c $\mathrm{U}$ mr., que son quinientas mill mrs.

Que todavía les suplicáys que sean contentos e seruidos, por las cosas ya dichas, con los dichos xx caualleros, que la çibdad que cada día fase tanto seruiçio, algund descanso ha de aver, y más que otra alguna.

Y para mejor negoçiar el asyento de los iij annos venideros desde Santa María en adelante, avéys primero de fablar con Formisedo e con los diputados de Seuilla e con el tesorero, o quien más entendáys. E sabed qué orden tyenen dado los diputados generales con Seuilla e con sus diputados en rasón de la gente de cauallo con que le ha de seruir la çibdad desde Santa María de Agosto en adelante. Por que visto este asyento de lo que primero tenía por cabeça e de lo que dello se le descarga desde Santa María de Agosto en adelante, proueáys con mejor seso lo que entendáys que conuiene al bien de la çibdad. Porque es çierto que sy a Seuilla dexaron quarto de caualleros, a Xeres deuen dexar meytad, segund los dichos seruiçios que ella fase e lo que en ellos cada vn día gasta. E para vos ayudar desto, conformadvos con todos los que vos entendierdes ayudar. 
(Al margen) Carta de fyn e quito. Y sy asyento fisierdes con los dichos diputados generales en lo de adelante, devéys de traer dello escriptura firmada e sygnada e abtorisada de los dichos diputados e del dicho Alfonso de Quintanilla, en manera que faga fe, para que Xeres la tenga para guarda de su derecho.

(Al margen) Carta de pago. Ítem, avéys de traer carta de pago e de fin e quito del seruiçio de los dichos caualleros, desde que pagardes el sueldo dellos fasta el dicho día de Santa María de Agosto, de los dichos generales e diputados e de Alonso de Quintanilla.

Ítem, avéys de traer carta de pago de Alfonso de Quintanilla, de cómo reçibió de vos los x U mr. del cumplimiento de su cauallería.

Ítem, avéys de traer carta de pago de la sennora duquesa de Villahermosa, de cómo reçibió desta çibdad los xx U mr. que restauan de las dos lanças quel sennor duque de Villahermosa ovo de aver desta çibdad, o de lo que dellos les pagardes, contando todavía sobre los vjU mr. que reçibió el dicho Aluar Lopes, xx iiij ${ }^{\circ}$. (Al margen) Esta carta de pago non la pidáys, porque queda en poder de Antón Franco el libramiento del duque e su carta de pago, saluo carta de pago de Pedro del Algaua, que los ha de reçebir.

Ítem, mirad que, por ley de Hermandad, en las primeras juntas fue ordenando que cada çibdad o villa o prouinçia touiese presta la gente de cauallo que le copiese, para la dar cada e quando le fuese demandado para los casos de la Hermandad. Por ende, muestrenvos quando fueron llamados los caualleros y quando no fueron.

Todo lo qual, esta çibdad vos remite, recorriendo todavía en las cosas que touierdes duda a escreuir a esta çibdad sobre ello e sobre las cosas que bierdes que deue ser consultada la çibdad.

Bartolomé Núñez (rubricado). Iohannes, bachalarius (rubricado).

\section{$\mathrm{V}$}

\section{VI.18. Sevilla.}

Asiento que los mandaderos de Jerez de la Frontera establecieron con los diputados generales de la Hermandad.

A. Archivo Municipal de Jerez de la Frontera. Archivo Histórico Secreto, caja 3, no 49, ff. $8-10$.

B. Archivo Municipal de Jerez de la Frontera. Actas Capitulares, 1478, ff. 2r-3r.

${ }^{8 r}$ Obligaçión de Xeres.

Hermandad.

En la muy noble y muy leal çibdad de Seuilla, a dies e ocho días del mes de junio anno del nasçimiento del Nuestro Sennor Ihuxpo de mill e quatroçientos e setenta e ocho annos, Pedro Camacho, veynte e quatro de la noble çibdad de Xeres, e Pedro Camacho, jurado della, en nombre e por virtud del poder que tyenen de la dicha çibdad, fisieron asyento y yguala con don Iohan de Ortega, prouisor de Villafranca, e con Alfonso de Quintanilla, contador mayor de cuentas del rey e de la reyna, nuestros sennores, y del su Consejo, y Iohan de Almarás, regidor e diputado general por la çibdad de Salamanca e su prouinçia, en nombre e por virtud de los poderes que tyenen de los dichos sennores rey e reyna, nuestros sennores, e del reuerendo sennor obispo de Cartajena e de los otros diputados generales de la Hermandad de los tres estados de Castilla y de León, de todo el sueldo e acostamiento que la dicha çibdat ovo a pagar de las lanças con que fue tenuda e obligada de seruir a la 
dicha Hermandad, fasta el día de Santa María de Agosto primera que verná deste dicho anno, que es fecha esta avenencia. Que avían de ser treynta e seys lanças, demás de las tres lanças que ouieron de pagar: las dos, al sennor duque don Alfonso, para en cuenta de las lanças que ouo de aver, e la vna a Alfonso de Quintanilla, para en cuenta de las lanças (toto) por rasón de su ofiçio de contador.

E por quanto la dicha çibdad ovo de cumplir las dichas lanças, e por algunos ynconuinientes que se trauesaron asý con el capitán de la dicha çibdad de Seuilla, como por el seruiçio de la dicha çibdad de Xeres en el çerco de Vtrera, como por otras çiertas veses en que salieron en seguimiento de los moros, donde perdieron e se les aguaron muchos cauallos e fesieron muchas costas, e por que lo suplicaron al rey e reyna, nuestros sennores, fue ygualado con los dichos veynte e quatro e jurado de la dicha çibdad por todo el dicho sueldo fasta el dicho día de Santa María de Agosto, que diesen e pagasen çiento e veynte e çinco mill mrs. para pagar la gente que ouiere seruido e seruiere por la dicha çibdad fasta el dicho día de Santa María de Agosto. Con los quales dichos çiento e veynte e çinco mill, la dicha çibdad e vesinos e moradores della sean libres e quitos de toda la gente con que ouieron de seruir fasta el dicho día de Santa María de Agosto, e de las faltas del seruiçio que ouieron de seruir e non syruieron; $y$, asýmismo, de toda la contribución de las pagas que se le pudieren cargar que avía de dar, asý al capitán de la dicha çibdad e su prouinçia, como al diputado prouençial, como todas las penas e achaques que por seruiçios o en otra qualquier manera que a la dicha çibdad pudieran ser demandados $/{ }^{8 v}$ por rasón de la dicha Hermandad fasta el dicho día de Santa María de Agosto.

La qual conueniençia e yguala e quita fesieron los dichos don Juan de Ortega, prouisor de Villafranca, e Alfonso de Quintanilla e Juan de Almarás, diputados e contador, por virtud de los dichos poderes que tyenen de la Diputaçión General, e de los dichos rey e reyna, nuestros sennores, con los dichos Pedro Camacho, veynte e quatro, e Pedro Camacho, jurado, en nombre de la dicha çibdad. E con los dichos çiento e veynte e çinco mill mrs., dieron por quita a la dicha çibdad de todo lo sobre dicho, como dicho es. E otorgaron carta de pago por ante mí, Pedro Sánches de Logronno, escribano general de la dicha Hermandad, firmada de sus nombres e firmada de mí el dicho Pedro Sánches, secretario de la dicha Hermandad.

Otrosý, los dichos Pedro Camacho, veynte e quatro, e Pedro Camacho, jurado, por virtud de los dichos poderes, en nombre de la dicha çibdad, fesieron asyento e conuenençia con el rey e la reyna, nuestros sennores, e en su presencia, e con los dichos don Juan de Ortega e Alfonso de Quintanilla e Juan de Almarás, diputados generales, en nombre de la Diputaçión General de los dichos reynos, para que ayan de dar e pagar, e den e paguen, por rasón del seruiçio que la dicha çibdad de Xeres ha de faser a los dichos rey e reyna, nuestros sennores, e a la dicha Hermandad, desde el dicho día de Santa María de Agosto primera que verná fasta tres annos complidos, primeros syguientes, vno en pos de otro, quatroçientas mill mrs. en cada anno, puestos en la çibdad de Seuilla, en poder de Alemán Pocasangre e de Juan de Lugo o de qualquier dellos tesoreros de la Hermandad, puestos por los dichos rey e reyna, nuestros sennores, e por los dichos diputados en nombre de la Hermandad de los dichos reynos, e non por ser tesoreros de la paga de la dicha çibdad de Seuilla.

E que sean tenudos de dar e pagar los dichas quatroçientas mill mrs. en esta guisa: los çient mill mrs. dellos en fyn del mes de agosto primero que viene; e los otros çient mill mrs. en fyn del mes de nouiembre deste dicho anno; e los otros çient mill mrs, en fyn del mes de abril del anno adelante primero venidero de mill e quatrocientos e setenta e nueue annos; e los otros çient mill mrs, en fyn del mes de mayo primero del dicho anno primero venidero. E a estos mismos plasos en cada vno de los otros dichos dos annos, para cumplimiento de los dichos tres annos, que se cumplirán por el día de Santa María de Agosto del anno que verná de mill e quatrocientos e ochenta e vno annos. 
De las quales dichas quatroçientas mill mrs. se han de reçebir en cuenta a la dicha çibdad de Xeres, en cada anno, dies mill mrs., que les damos para ayuda de las costas de la procuraçión e sostenimiento de los ofiçiales de la justiçia, que con los dichos veynte e quatro e jurado asentaron que se les dexasen e diesen para los gastos e salarios de los ofiçiales e para las cosas tocantes a la esecuçión de la dicha Hermandad de la dicha çibdad. Los quales dichos dies mill mrs. les han de ser descontados e rreçebidos en cuenta, por los dichos tesoreros, por rata, en cada paga lo que les montare aver. Asý que han de quedar en los dichos tesoreros tresientas e nouenta mill mrs. en cada vn anno para la paga de la dicha gente e costas que la dicha çibdad de Xeres ha de pagar e complir por el seruiçio de la dicha Hermandad, de los dichos tres annos. Con las quales, la dicha çibdad sea libre de non pagar ninguna otra cosa por rasón de la dicha Hermandad, nin armas, nin cauallos, nin otras pérdidas algunas de la dicha gente.

Obligáronse, por virtud de los dichos poderes en nombre de la dicha çibdad de Xeres, los dichos Pedro Camacho, veynte e quatro, e Pedro Camacho, jurado, que la dicha çibdat e vesinos e moradores della darán e pagarán las dichas tresientas e nouenta mill mrs. a los dichos tesoreros, puestas en la dicha çibdad de Seuilla en cada vno/ ${ }^{9 \mathrm{r}}$ de los dichos tres annos, a los dichos plasos suso contenidos, e a cada vno dellos. So pena que por cada día que pasare de cada vno de los dichos plasos, que la dicha çibdat de Xeres non finiere la dicha paga de los dichos mrs., en la manera susodicha, pechen e paguen de pena cada día mill mrs. de quantos días pasaren, los quales sean para las costas e gastos de la dicha Hermandad, por los quales se faga entrega e esecuçión en bienes de la dicha çibdad e vesinos e moradores della, asý como por los mrs. del prinçipal.

E otrosý, que darán e pagarán los dichos dies mill mrs. en cada anno para la paga de los dichos ofiçiales e esecuçión de la justicia, como dicho es. E más, que cumplirá la dicha çibdad lo que falta de los dichos dies mill mrs. para pagar las personas que tyenen e han de tener cargo de la gouernaçión de la justiçia de la dicha çibdat de Xeres, segund se contiene en los capítulos e que con los dichos veynte e quatro e jurado, los dichos sennores diputados generales fesieron e asentaron, que está asentado en el libro del dicho Alfonso de Quintanilla, e pasó por ante el dicho Alfonso Sánches, secretario de la dicha Hermandad.

E los dichos don Juan de Ortega e Alfonso de Quintanilla e Juan de Almarás, por virtud de los poderes que tyenen de los dichos rey e reyna, nuestros sennores, e de la dicha Diputaçión General de los dichos reynos, otorgaron los susodicho e se obligaron que su altesa e la dicha Diputaçión e Junta General de los dichos reynos lo avrán por rato e firme. Sobre lo qual todo, amas las dichas partes, los dichos diputados en nombre de los dichos reynos e por mandado de los dichos rey e reyna, nuestros sennores, e los dichos Pedro Camacho, veynte e quatro, e Pedro Camacho, jurado, en nombre de la dicha çibdad, otorgaron dos contratos en vn tenor para cada vno de las partes el suyo, en que renunçiaron las leyes e obligaron los bienes de las dichas sus partes, asý a la dicha debda prinçipal como a la pena, sy en ella cayeren. E los dichos diputados avrán por firme el dicho asyento e concordia e quita que a la dicha çibdad fisieron, so pena que les darán e pagarán los dichos çiento e veynte e çinco mill mrs., que asý dieron e pagaron del seruiçio fasta el dicho día de Santa María de Agosto, e todos los otros dichos maravedís que ouieron pagado del dicho asyento de los dichos tres annos adelante venideros con el doblo.

Para lo qual todo, otorgaron los dichos contratos con renunçiaçiones de leyes a consejo de letrados, qual conuiniere a cada vna de las dichas partes, por ante el dicho Pedro Sánches, para que lo de firmado e signado. E firmaron cada vno dellos sus nombres en este registro, en presençia de los testigos de yuso escriptos, que a ello estouieron presentes.

Alonso de Quintanilla (rubricado). Juan de Almarás (rubricado), Pedro Camacho de Villaviçençio (rubricado). El jurado Pedro Camacho (rubricado). 
(Al margen) Otorgo e apruebo este asiento en lo que toca a la çeuil e non al. El provisor, Juan Ortega.

Testigos que fueron presentes a todo lo susodicho, e vieron firmar aquí sus nombres a los dichos sennores diputados generales e a los dichos Pedro Camacho, veynte e quatro, e Pedro Camacho, jurado de la dicha çibdad de Xeres, Pedro de las Ruelas e Alfonso Péres Melgarejo, veynte e quatros de la dicha çibdad de Seuilla e Fernando de Arana, escriuano en la dicha çibdat de Seuilla, y el dotor de Azamar, del Consejo del rey e reyna, nuestros sennores, e Diego de Sant Andrés, escribano de cámara del dicho sennor rey. E yo, el dicho Pedro Sánches de Logronno, secretario e escribano general de la dicha Hermandad e escribano de cámara del dicho sennor rey e su notario público en la su corte e en todos los sus regnos e sennoríos, que fuy presente a lo que dicho es, en vno con los dichos testigos por ruego e otorgamiento de los dichos sennores diputados e de los dichos Pedro Camacho, veynte e quatro, e Pedro Camacho, jurado, vesinos de la dicha çibdad de Xeres, esta escriptura de yguala e conveniencia e obligaçión para la dicha çibdad de Xeres, escriuí e fís aquí este mio signo a tal y en testimonio de verdad. Pero Sánches (signo).

\section{VI}

\section{VII.7. Sevilla.}

Asiento acordado entre los diputados generales y el concejo de Sevilla sobre la contribución de este y de su alfoz a la Hermandad

A.- Archivo Municipal de Sevilla, Actas Capitulares, 1478, carp. 86, fs. 40r-43v.

En la muy noble e muy leal çibdad de Seuilla, martes siete días del mes de jullio, anno del nasçimiento de Nuestro Saluador Ihuxpo de mill e quatroçientos e setenta e ocho annos. Don Juan de Ortega, prouisor de Villafranca, sacristán mayor del rey, nuestro sennor, e Alfonso de Quintanilla, contador mayor de cuentas del rey e de la reyna, nuestros sennores, y del su Consejo, e Juan de Almarás, regidor e diputado de la noble çibdad de Salamanca, todos tres diputados generales de los reynos de Castilla e de León, por virtud de los poderes a ellos dados por el dicho rey, nuestro sennor, e por la Diputaçión General de la Hermandad de los tres estados destos dichos reynos, y en su nombre, fisieron asyento con los caualleros veynte e quatro regidores e jurados de la dicha çibdad de Seuilla, y, en su nombre, como diputados por la dicha çibdad, Juan de Pineda, García Tello, Luys de Touar, Ferrando de Abreu, Alfonso Peres Martel, Roelas, Alfonso Peres Melgarejo, el bachiller Luys Sanches, Alfonso de las Casas, regidores de la dicha çibdad, y el jurado Gonçalo Çereso, y el jurado Françisco de Alfaro, que para ello fueron diputados por la dicha çibdad, aprouando e consintyendo con el dicho sennor rey, nuestro sennor, e por el dicho ayuntamiento de la dicha çibdad.

E todos, después de mucho platycado, fueron concordados que el cuerpo de la dicha çibdad de Seuilla ouiese de dar en seruiçio al dicho sennor rey e ayudase a los dichos reynos para sostenimiento de las dichas Hermandades cada vno de los tres annos adelante venideros por las dichas Hermandades que fueron alargadas, que començará por Santa María de Agosto primera que viene deste dicho anno, e se cumplirá por Santa María de Agosto del anno de mill e quatrocientos e ochente e vn annos, con vn cuento e tresientas mill mrs. en cada anno. Con la qual suma de maravedís de vn cuento e tresientas mill mrs. se cumplan e ayan de complir las cosas que adelante serán declaradas, asý para la esecuçión de la justiçia 
e gasto de los ofiçiales que lo an de faser e esecutar en el dicho cuerpo de la dicha çibdad de Seuilla, como para el gasto del diputado general, que la dicha çibdad ha de tener y de enbiar a la Diputación General de los dichos reynos, como para el gasto de lo que copiere al diputado prouinçial que ha de ser puesto en esa prouinçia, como para pagar las lanças que an de ser asentadas al duque don Alfonso, hermano del rey, nuestro sennor, e, asý mismo, para las lanças que ha de ${ }^{/ 40}$ aver el dicho Alfonso de Quintanilla, por contador de la dicha Hermandad, como para pagar al capitán de la prouinçia de la dicha çibdad de Seuilla, [lo] que le copiere por rata segund las lanças que de la dicha çibdad troxere en su capitanía. En tal manera que con el dicho vn cuento y tresientas mill mrs. la dicha çibdad sea libre de todas las costas e gastos que a la dicha Hermandad ha de ayudar, e a los dichos rey e reyna, nuestros sennores, seruir, e que pagándose las dichas costas que aquí serán declaradas para en prouecho y bien e vtylidad de la dicha çibdad e vesinos e moradores della, que son las que adelante serán contenidas, en esta guisa.

Primeramente, que sean pagados a dos alcaldes de la Hermandad que aya en la dicha çibdad de Seuilla, vno del estado de los caualleros e escuderos e otro del estado de los çibdadanos e pecheros, treynta mill mrs. Los veynte mill al alcalde del estado de los caualleros e escuderos, e dies mill mrs. al alcalde del estado de los çibdadanos e pecheros. Los quales alcaldes sean tenudos de poner tales que les convenga a la esecuçión de la justiçia e al ayuntamiento de la dicha çibdad en sus conçiençias, por el tiempo que las leyes de la Hermandad disponen, e a ellos bien visto fuere. E los tesoreros de la Hermandad en la dicha çibdad sean thenudos, syn otro libramiento alguno, de pagar los dichos treynta mill mrs. a los dichos alcaldes e a cada vno dellos la quantía suso declarada por terçios de cada vn anno, desde el día de Santa María de Agosto primero que verná en adelante, en fin de cada terçio lo que montare, trayendo fee del escribano del ayuntamiento de la dicha çibdad de cómo son elegidos por alcaldes e an seruido el dicho terçio. E con aquella fee, el contador de la dicha Hermandad sea thenudo de los reçebir en cuenta a los dichos tesoreros lo que ansý montare aver a cada vno de los dichos alcaldes ............... xxx U mr.

(Al margen, quadrilleros) Otrosý, se an de pagar más trese quadrilleros que la dicha çibdad ha de tener en ella, con vn quadrillero mayor para que tenga las quadrillas hordenadas e enquadrilladas, para quando fueren menester/40v llamar alguna gente para la exsecuçión de la justiçia. Los quales dichos quadrilleros, con el dicho quadrillero mayor, hayan los trese, cada vno dellos, mill mrs. por anno de quitación, y el dicho quadrillero mayor, con el qual serán catorse quadrilleros, aya dos mill mrs. En tal manera, que los dichos catorse quadrilleros, porque siruan el dicho ofiçio por vn anno, ayan los dichos quinse mill mrs. E que cada collaçión de la dicha çibdad donde sean nombrados los dichos quadrilleros, sean tenudos sienpre de los tener por el dicho salario, puesto que alguno dellos se vaya o muera o mude de la dicha collaçión, so pena que la tal collaçión que lo non cunpliere pague dos mill mrs. de pena para el arca de la dicha Hermandad . . . . . . . . . . . . . . . Xv U mr.

(Al margen, depósito e salario de quadrilleros) Otrosý, que los dichos quadrilleros sean tenudos de yr con las cartas e mandados de los alcalldes e diputado prouinçial sobre las cosas tocantes a la exsecuçión de la justiçia e otras cosas de la Hermandad. Y que estos que asý fueren, de más del dicho su salario ayan por los días que trabajaren treynta mrs. cada día. E que estos treynta mrs. cada día al que los ganare se paguen de dies mill mrs. que los dichos tesoreros tengan aparte, para los gastos y exsecuçión de la justiçia. Y den cuenta dellos a los alcalldes e diputado prouinçial. E que estos dies mill mrs. se pongan en cada vn anno en vna bolsa aparte para la dicha exsecuçión de la justiçia. E sy en vn anno non se gastaren, lo que sobrare esté sienpre en cabdal, que vn anno se pueda gastar más e en otro se pueda gastar menos. Los quales dichos dies mill mrs. se han de poner del dicho vn cuento e tresyentas mill mrs., que la dicha çibdad ha de dar en cada vn anno .......... . U mr. 
(Al margen, penas) Otrosý, que todas las penas que fueron puestas para el arca de la Hermandad a qualesquier personas, o aquellas en que qualesquier presonas cayeren, que son del ofiçio e juridiçión de los dichos alcalldes de la Hermandad, sean por los dichos alcalldes judgadas. E aquellas que asý fueren/4lr judgadas se cobren e sean puestas en poder de los dichos tesoreros, e les sea fecho cargo dellas por antel escriuano de la Hermandad, y los tengan para la prosecución de la justiçia e seguimiento de los ladrones, demás de los dichos dies mill mrs. que asý han de tener cada anno del dicho vn cuento e tresyentas mill mrs.. E que de todo den cuenta e rasón cada que les fuere pedida, asý por los alcalldes e diputado prouinçial como por el contador de la dicha Hermandad.

(Al margen, requerir la tierra) Otrosý, por quanto conviene que los alcalldes de la Hermandad de la dicha çibdad vna ves en el anno salgan a andar por la tierra e la visitar sy se fase justiçia y remediar los agrauios que fallaren. E averán menester, esta ves que salieren, al que fuere a las Sierras, quarenta días; e al que fuere a la Campinna, ha menester vna ves que fuere, treynta días; que son más veses en el anno, setenta días. A los quales se tasan para su mantenimiento, demás de su salario, siete mill e quinientos mrs., en esta guisa: al alcallde del estado de los caualleros y escuderos, quatro mill e quinientos mrs.; e al alcallde de los çibdadanos y pecheros, tres mill mrs. Y que el escriuano aya por yr con los dichos alcalldes a las Sierras e al Canpo (sic), en la manera que dicha es, dos mill mrs. Que son e montan todo lo que los dichos alcalldes y escriuano han de aver, en la manera que dicha es, nueue mill y quinientos mrs., los quales les han de pagar los dichos tesoreros del dicho vn cuento e tresyentas mill mrs. . . . . . . . . . . . . . . . . . . . . . . ix $\mathrm{U} \mathrm{d} \mathrm{mr.}$

(Al margen, exsecutor) Otrosý, que aya vn exsecutor general para la exsecuçión de las cosas de esta prouinçia, el qual llieue (sic) los derechos de la exsecuçión que fesiere justamente, es a saber: que llieue (sic) quarenta mrs. al millar fasta en contía de çinco mill mrs. de exsecuçión. Y sy la exsecuçión pasare a mayor contía de los dichos ${ }^{41 v}$ çinco mill mrs., que non llieue (sic) más de fasta dosientos mrs. por qualquier exsecuçión que faga, como se fase en los maravedís del rey. E más, que aya de salario dies mill mrs. cada anno, los quales le sean pagados del dicho vn cuento e tresyentas mill mrs.; e ge los paguen los dichos tesoreros por terçios de cada vn anno, en fin de cada vn terçio, lo que montare........ x U mr.

(Al margen, letrados) Otrosý, que los dichos tesoreros paguen a los letrados de la Hermandad dose mill mrs. cada anno, para que aconsejen a los alcaldes la exsecuçión de la justiçia. E que estos se paguen a los letrados que continuamente los ouieren de aconsejar, que sean nombrados por los diputados generales e por el diputado prouinçial seys mill mrs. en cada anno; e los otros seys mill mrs. se paguen por (blanco) a los letrados que los dichos alcalldes en sus conçiençias les converrná dar a presonas que non sepan que son letrados conosçidos, que los ayan de aconsejar ....................

(Al margen, diputado general) Otrosý, han de pagar del dicho vn cuento y tresientas mill mrs. al diputado general que fuere de la dicha çibdad y residiere en la Diputaçión General, de todo el tiempo que residiere, contando las ydas e venidas a su casa, a rasón de tresientos mrs. cada día, que le monta al anno çiento e ocho mill mrs. El qual dicho diputado general ha de ser a contentamiento del rey, nuestro sennor, e de la Diputaçión General, pues que su altesa consiente que se pague de aquello que a su altesa dan en seruiçio para la dicha Hermandad. E ha de ser pagado lo que se le diere por carta de los otros diputados generales, e sobrescripta del contador mayor, e non en otra manera. ........... c viij U mr.

(Al margen, tesoreros) Otrosý, se han de pagar más a los tesoreros Alemán Pocasangre e Juan de Lugo del dicho vn cuento e tresientas mill mrs. que han de resçibir de la dicha çibdad de Seuilla, a rasón de a veynte mrs. al millar por los resçibir e pagar, que montan en el dicho vn cuento e tresientas mill mrs. veynte e seys mill mrs. .......... xx vj $\mathrm{U} \mathrm{mr} .{ }^{42 r}$. 
(Al margen, diputado prouinçial) Otrosý, se han de pagar del dicho vn quento e tresientas mill mrs. al diputado prouinçial, que ha de tener cargo en la dicha çibdad de Seuilla y su tierra de ver cómo los alcalldes fasen la justiçia; e, asýmismo, por que ande e vesyte la dicha tierra, y faga que se les faga justiçia, sy menester la ouieren; y, asýmismo, para faser cobrar los maravedís de la çibdad y los de la tierra y prouinçia, siendo requerido por los tesoreros, y mirar que no se faga exsecuçión en los labradores contra justiçia; e para dar fauor e ayuda a los dichos tesoreros para cobrar los maravedís que quedan a su cargo de los dichos tesoreros; e tanbién, asýmismo, este diputado sea tenudo tres veses en el anno, de quatro en quatro meses, aver faser vn alarde a la gente de la prouinçia, con su logarteniente de Alfonso de Quintanilla, o con él, si ende estouiere. E aya este diputado veynte mill mrs. del dicha vn

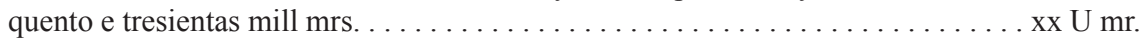

(Al margen, capitán) Otrosý, han de ser pagados del dicho vn quento y tresientas mill mrs., çinquenta mill mrs. al capitán de la gente del Arçobispado de Seuilla, por rasón de çinquenta lanças que ha de tener en esta capitanía de la dicha çibdad de Seuilla. . . . . I U mr.

(Al margen, capitán general) Otrosý, se han de pagar más al yllustre sennor duque don Alfonso, hermano del rey, nuestro sennor, en cuenta de las lanças que le han de ser pagadas para su gente y de las que caben en este Arçobispado de Seuilla, çinco lanças. Las quales han de ser pagadas a rasón de quinze mill mrs. cada lança, que montan las dichas çinco lanças setenta y çinco mill mrs. . . . . . . . . . . . . . . . . . . . lxx v U mr.

(Al margen, contador) Otrosý, han de pagar más del dicho vn quento e tresientas mill mrs. para Alfonso de Quintanilla, contador mayor, e para su logarteniente, dos lanças, a respecto de cómo se han de pagar las de dos escuderos, que son dies e siete mill y quinientos mrs. cada lança, que montan treynte e çinco mill mrs./42v . . . . . . . . . xxx v U mr.

Otrosý, se han de pagar más çinquenta lanças, que anden en la dicha capitanía, e syruan por la dicha çibdad, las quales se an de tomar a preçio que con los escuderos se podieren ygualar, con tanto que no pase el preçio de dies e ocho mill mrs. Con los quales maravedís le han de pagar sueldo, acostamiento e pérdidas de cauallos. Por tal manera, que el concejo y los thesoreros no sean obligados de les dar otra cosa, saluo el preçio que les fuere ygualado, e de ge lo pagar cada mes lo que montare en dinero contado, donde quiera que estouiere el capitán con la dicha gente. Que monta en lo que asý an de pagar a las dichas çinquenta lanças, nueueçientas mill mrs. ...................................

Otrosý, se han de pagar al escribano de la dicha Hermandad, que es Juan de Pyneda, por que ponga escribano que syrua el ofiçio a su costa, lleuando los derechos ordynarios, quinze mill mrs. ...................................

Otrosý, se han de pagar más al carçelero por el cargo que tyene de guardar los presos e poner recabdo en ellos, mill e quinientos mrs. ................. $\mathrm{U} \mathrm{d} \mathrm{mr.}$

Asý que montan todos los dichos maravedís que asý han de pagar a las dichas personas susodichas, segund y en la manera y forma que dicha es, vn cuento y tresientas y veynte e dos mill e quinientos mrs. En tal manera que faltan aquí, que se ha de complir de otra parte, veynte e dos mill e quinientos mrs., los quales se paguen de los maravedís que los thesoreros ovieren de resçebir de qualesquier penas................. j q $\mathrm{ccc}^{\mathrm{x} x} \mathrm{ij} \mathrm{Ud} \mathrm{mr}$.

Alfonso de Quintanilla (rubricado)/43r.

(En el margen izquierdo) j q $\mathrm{o}^{\mathrm{c}} \mathrm{ccc} \mathrm{xvij} \mathrm{U} \mathrm{mr}$.

$$
* * *
$$

Otrosý, los dichos caualleros veynte e cuatros e jurados, diputados por la dicha çibdad para entender en los dichos fechos de la Hermandad, se concordaron por todas las villas e 
logares de la tierra de Seuilla, para que syruan a los dichos sennores rey e reyna en cada vn anno con vn cuento e seysçientas mill mrs. por cada anno de los tres annos, que començarán por el día de Santa María de Agosto primero que verná deste anno en que estamos, e se complyrá por el anno de ochenta e vno.................... j q dc U mr.

Del qual dicho vn cuento e seysçientas mill mrs. se an de seruir ochenta lanças, al dicho presçio de dies e ocho mill mrs., que son vn cuento e quatroçientas e quarenta

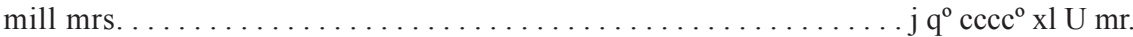

Otrosý, han de dar al capitán de la gente, a rasón de mill mrs. por lança, que son ochenta lanças, ochenta mill mrs. . . . . . . . . . . . . . . . . . .

Otrosý, han de pagar más a los thesoreros de la dicha çibdad, que han de tener cargo de pagar la gente de la dicha çibdad e de la dicha tierra, treynta e dos mill mrs., que le monta aver de su salario, a rasón de veynte mrs. al millar. ............. xxx ij U mr.

Otrosý, se an de tomar más çinquenta mill mrs., en cuenta de lo que han de aver para dies espyngarderos, que han de estar en la dicha capitanía, en cada anno, a rasón de dose mill mrs. a cada espyngardero, çiento e veynte mill mrs., e los otros setenta mill mrs. se an de pagar de los otros lugares de la prouinçia. .................

Suma vn cuento e seysçientas e dos mill mrs., ansý que faltan aquí dos mill mrs., que se an de complyr de otra parte e logares de la prouiçia e de lo que se descuenta a los es-

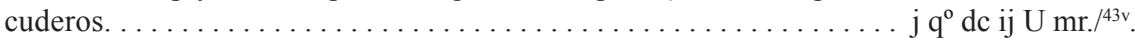

\section{BIBLIOGRAFÍA}

Carriazo, Juan de Mata y Carande, Ramón. El Tumbo de los Reyes Católicos del concejo de Sevilla, t. I, Sevilla, 1968.

Guerrero Navarrete, Yolanda. "La Hermandad de 1476 y Burgos. Un factor decisivo en la transformación del poder municipal a fines de la Edad Media", Anuario de Estudios Medievales, 16 (1986), p. 533-555.

Ladero Quesada, Miguel Ángel. La Hacienda Real de Castilla en el siglo XV, La Laguna, 1973, p. 214.

López Martínez, Celestino. La Santa Hermandad de los Reyes Católicos, Sevilla, 1921.

Navarro Sáinz, José Ma “"Aproximación al estudio de la Hermandad General bajo los Reyes Católicos en Sevilla y su tierra (1477-1498)", Historia, Instituciones, Documentos, 33, 2006.

Rufo Ysern, Paulina. "La fiscalité extraordinaire à Ecija à la fin du Moyen Âge: imposiciones et sisas”, en D. Menjot, M. Sánchez Martínez (coord.). La fiscalité des villes au Moyen Âge (occident méditerranéen. 2. Les systèmes fiscaux, Editions Privat, Toulose, 1999, p. 485-496.

Sánchez Benito, José M ${ }^{\mathrm{a}}$ y Morales Muñiz, Dolores Carmen. "La implantación de la Hermandad General en tierras de la nobleza: los estados del duque de Alba (1476-1479), En la España Medieval, 16 (1993), p. 265-286.

Sánchez Benito, José Ma " "Observaciones sobre la Hermandad castellana en tiempos de Enrique IV y los Reyes Católicos”, Espacio, Tiempo y Forma. Serie III, Historia Medieval, 15 (2002), p. 209-244. 
Terán Sánchez, Antonio Collantes de. "Los comienzos de la Santa Hermandad de los Reyes Católicos en Andalucía (1476-1481)", Minervae Baeticae. Boletín de la Real Academia Sevillana de Buenas Letras, 42 (2014), en prensa.

Fecha de recepción del artículo: marzo de 2014

Fecha de aceptación y versión final: mayo de 2014 